NBER WORKING PAPER SERIES

\title{
EXPECTED RETURNS, YIELD SPREADS, AND ASSET PRICING TESTS
}

\author{
Murillo Campello \\ Long Chen \\ Lu Zhang
}

Working Paper 11323

http://www.nber.org/papers/w11323

\section{NATIONAL BUREAU OF ECONOMIC RESEARCH 1050 Massachusetts Avenue \\ Cambridge, MA 02138 \\ May 2005}

We thank Mike Barclay, Dan Bernhardt, Lawrence Booth, Cam Harvey (the editor), Raymond Kan, Jason Karceski, Naveen Khana, Mark Schroder, Jay Shanken (the AFA discussant), Jerry Warner, Jason Wei, Jim Wiggins, Tong Yao, Guofu Zhou, seminar participants at University of Notre Dame and at the AFA meetings in 2005, and especially an anonymous referee for helpful comments and suggestions. The usual disclaimer applies. The views expressed herein are those of the author(s) and do not necessarily reflect the views of the National Bureau of Economic Research.

(C2005 by Murillo Campello, Long Chen, and Lu Zhang. All rights reserved. Short sections of text, not to exceed two paragraphs, may be quoted without explicit permission provided that full credit, including () notice, is given to the source. 
Expected Returns, Yield Spreads, and Asset Pricing Tests

Murillo Campello, Long Chen, and Lu Zhang

NBER Working Paper No. 11323

May 2005

JEL No. G12, E44

\begin{abstract}
We use yield spreads to construct ex-ante returns on corporate securities, and then use the ex-ante returns in asset pricing assets. Differently from the standard approach, our tests do not use ex-post average returns as a proxy for expected returns. We find that the market beta plays a much more important role in the cross-section of expected returns than previously reported. The expected value premium is significantly positive and countercyclical. We find no evidence of ex-ante positive momentum profits.

Murillo Campello

Department of Finance

University of Illinois at Urbana-Champaign

340 Wohlers Hall, MC 706

1206 South Sixth Street

Champaign, IL 61820

campbello@uiuc.edu

Long Chen

Department of Finance

Michigan State University

327 Eppley Center

East Lansing, MI 48823

chen@bus.msu.edu

Lu Zhang

Simon School

University of Rochester

Carol Simon Hall 3-160B

Rochester, NY 14627

and NBER

zhanglu@simon.rochester.edu
\end{abstract}




\section{Introduction}

The standard asset pricing theory argues that investors should demand an ex-ante premium for acquiring risky securities (e.g., Sharpe (1964), Lintner (1965), and Merton (1973)). In practice, because the ex-ante risk premium is not readily observable, empirical asset pricing studies often use ex-post, average realized equity returns as a proxy for expected equity returns. This commonplace strategy is justified on grounds that for sufficiently long horizons the average return will "catch up and match" the expected return on equity securities ex-post average excess equity returns provide for an easy-to-implement, seemingly unbiased estimate of expected equity risk premium.

Despite its popularity, the above strategy has potentially serious limitations. ${ }^{1}$ In particular, the average realized return might not converge to the expected risk premium in finite samples. $^{2}$ This, in effect, conditions any inferences based on ex-post returns on the properties of the particular data under examination. In his AFA presidential address, Elton (1999) observes that there are periods longer than ten years during which stock market realized returns are on average lower than the risk-free rate (1973 to 1984), and periods longer than 50 years in which risky bonds on average underperform the risk-free rate (1927 to 1981). Based on this "counter-intuitive" evidence on risk and return, Elton proposes:

"[D] eveloping better measures of expected return and alternative ways of testing asset pricing theories that do not require using realized returns have a much higher payoff than any additional development of statistical tests that continue to rely on realized returns as a proxy for expected returns." (p. 1200)

As most findings in the empirical asset pricing literature were established (and are revisited) with the use of realized returns, it is natural to ask whether extant inferences about riskexpected return trade-off hold under an alternative, direct measure of expected return.

In this paper, we construct an ex-ante measure of risk premium based on data from bond yield spreads and investigate whether well-known equity factors, such as market, size,

\footnotetext{
${ }^{1}$ Earlier studies have discussed in some detail the noisy nature of average realized returns in a number of different contexts (see, e.g., Blume and Friend (1973), Sharpe (1978), and Miller and Scholes (1982)).

${ }^{2}$ Complexity in learning about asset pricing formation might also cause ex-post returns to deviate from their expectations (see Lewellen and Shanken (2002) and Brav and Heaton (2002)).
} 
book-to-market, and momentum, can explain the cross-sectional variation of expected (as opposed to average realized) stock returns. Our basic approach builds on the observation that debt and equity are financial claims written on the same set of real assets and hence must share common risk factors. In particular, our analysis explores this insight to show how one can use corporate bond data to glean information about investors' required equity risk premium. In what follows, we derive an analytical formula that links ex-ante equity risk premia and bond risk premia after adjusting bond yields for default risk, rating transition risk, and the tax spreads between the corporate and the Treasury bonds.

Why use bond data? While relevant information regarding a firm's systematic risk is incorporated both into its stocks and bonds, the latter reveal key insights about investors' return expectations. The first thing to notice is that bond yields are calculated in the spirit of forward-looking internal rates of return. To wit, bond yield is the expected return if the bond does not default and the yield does not change in the subsequent period. Importantly, current bond prices impound the probability of future default, and yield spreads contain the expected risk premium for taking default risk. Controlling for default risk, firms with higher systematic risk will have higher yield spreads; a relationship that holds period by period, cross-sectionally. This contrasts sharply with what one can learn from equity securities, whose prices reveal little conditional information about expected cash flows and discount rates - one has to rely on a long time series to "back out" the expected return. ${ }^{3}$

Secondly, notice that the time-variation of expected returns in the equity markets often works against the convergence of average realized returns to the expected return. Consider, for example, that investors require a higher equity risk premium from cyclical firms during economic downturns. To reflect this, those firms' equity prices should fall and their discount rates rise during recessions. Cyclical firms' equity values indeed fall during economic downturns, reflecting value losses in those firms' underlying assets. However, by averaging ex-post a cyclical firm's returns over the course of a recession, one might wrongfully conclude that the cyclical firm is less risky because of its lower "expected" return. Bond yield spreads,

\footnotetext{
${ }^{3}$ As pointed out by Sharpe (1978), the CAPM only holds conditionally and expected return might have nothing to do with future realized returns. Risk premia recovered from bond yields, in contrast, will reflect conditional information.
} 
in contrast, increase during recessions: yield spreads move in the same direction of the discount rate and they are higher for cyclical firms.

Our principal goal in this paper concerns the empirical applicability of a basic risk argument linking yield spreads and expected equity returns. Building on Merton's (1974) framework, we first formalize our ideas. We then test our pricing predictions using standard multi-factor models. In our view, the asset pricing tests of this paper provide fresh insights in to the determinants of the cross-section of expected returns, complementing the inferences based on average realized returns.

Our main findings can be summarized as follows. First, the market beta plays a more important role in explaining the cross-sectional variation of expected returns than previously documented. Its explanatory role remains significant even after we control for size, book-tomarket, and prior returns. This finding is striking given the well-publicized "weak" relation between market beta and ex-post average returns (see, e.g., Fama and French (1992)). In effect, our findings are more consistent with those of Kothari et al. (1995), who estimate market betas from annual return data and find economically and statistically significant compensation for beta risk. We conjecture that the market beta is more significant in our tests because ex-ante returns are much less noisy than ex-post returns.

Second, the expected value premium is significantly positive throughout our sample period (from 1973 to 1998). Moreover the ex-ante value premium is countercyclical. As a whole, our evidence supports the view that book-to-market captures relevant dimensions of risk that are priced ex-ante in equity returns (e.g., Fama and French $(1993,1996)$ ). In addition, it lends support to studies highlighting the effects of business cycles and conditional information on the value premium (e.g., Ferson and Harvey (1999) and Lettau and Ludvigson (2001)).

Third, we find that there are no ex-ante positive momentum profits. In fact, momentum is priced ex-ante with a negative sign. This finding is consistent with several interpretations. For example, one interpretation is that investors do not expect stocks with comparatively high prior returns to be riskier and earn higher returns in the future. In other words, momentum might not be an ex-anted priced risk factor, consistent with behavioral models of Barberis et al. (1998), Daniel et al. (1998), and Hong and Stein (1999). Alternatively, 
the ex-ante distribution of returns might deviate from the ex-post distribution of returns because of incomplete information and learning. In other words, ex-post returns might appear predictable to an econometrician, but investors can neither perceive nor exploit this predictability ex-ante (see Brav and Heaton (2002), Lewellen and Shanken (2002), and Shanken (2004)). Yet another interpretation for our findings is that momentum is an empirical by-product of using average realized returns as a (poor) proxy for expected returns. This interpretation, coupled with the fact that momentum strategies involve frequent trading in securities with high transaction costs (see Lesmond et al. (2004)), raises the possibility that momentum may be an "illusion" of profit-taking opportunity.

The remainder of the paper is organized as follows. Section 2 discusses related literature. Section 3 describes the construction of our expected equity risk premium. Section 4 reports our findings on the time series of common equity factors and on the cross-sectional variation of equity risk premium. Finally, Section 5 summarizes and interprets our results.

\section{Related Literature}

The empirical asset pricing literature has traditionally used average realized equity returns as surrogates for expected equity returns. Recently, several papers have experimented with alternative proxies for expected returns. Our work is largely related to this line of research, as well as to the literature on the relation between yield spreads and equity returns. We find it important to establish these connections here.

Linking expected equity returns to yield spreads has a long tradition in empirical finance. Harvey $(1986,1988)$ is among the first to link yield spreads to consumption growth, an important component of pricing kernels that affect expected returns. Chen et al. (1986) find that yield spreads are priced in equity returns. Ferson and Harvey (1991) and Harvey (1991) use the yield spreads as instruments for expected equity returns. Other examples include Keim and Stambaugh (1986), Campbell (1987), Fama and French (1989, 1993), and Jagannathan and Wang (1996). Importantly, all of those papers model expected market risk premium as a function of aggregate yield spreads. The novelty of our study is that we model firm-level expected returns as a function of firm-level yield spreads. In other words, while previous papers 
focus on the market equity premium, we focus on the cross-section of expected returns.

Recently, researchers have looked for alternative measures of expected returns. Brav et al. (2003) use analyst forecasts to construct the ex-ante equity risk premium (below we draw comparisons between our results and those of Brav et al.). Likewise, in an intriguing paper, Graham and Harvey (2003) obtain direct measures of the equity risk premium from surveying Chief Financial Officers of U.S. corporations. They find evidence of a variable one-year risk premium, but a more stable ten-year risk premium. Our work is also in the spirit of a stream of papers that use valuation models to estimate expected equity risk premium (examples are Blanchard (1993), Gebhardt et al. (2001), and Fama and French (2002)).

Also close in spirit is Vassalou and Xing (2004), who build on Merton's (1974) option pricing model to compute default likelihood measures for individual firms. They find that default risk has a significant impact on equity returns, and that the size effect and part of the value effect are driven by default risk. Our paper is related to theirs because we also use information from corporate debt to price corporate equity. However, differently from Vassalou and Xing, who use average realized returns, we use direct measures of expected returns. In a sense, our paper combines insights from both Vassalou and Xing and Brav et al. (2003). Another important connection with the literature concerns Bekaert et al. (2004), who present a model with stochastic risk aversion that is consistent with many stylized facts in the aggregate stock and bond markets. As Bekaert et al., we also explore the simultaneity between debt and equity pricing. Our focus, however, is on the cross-section of returns.

Above all, we differ from the existing literature because we use firm-level bond data to construct expected equity returns. In essence, we explore the part of investors' information set that is uniquely tied to investors' revealed preferences - their actual demand for risky corporate securities (bonds). Also new is our approach to recovering information from bond data. The details of this approach are provided in the next section.

\section{Constructing Expected Equity Returns}

This section describes the construction of expected equity returns based on bond data. Section 3.1 lays out the basic idea. Section 3.2 formalizes our argument through a series of 
propositions. Implementation details of our method are described in Section 3.3.

\subsection{The Basic Idea}

Our basic insight comes from the observation that bond and equity risk premia are intrinsically connected because bond and equity securities are contingent claims written on the same set of productive assets - an idea that can be traced back to Merton (1974). Using this link, we recover the ex-ante equity risk premium from the bond risk premium. From the definition of bond price as a function of bond yield, we back out the bond risk premium from the observable yield spreads, which are forward-looking. We then conduct asset pricing tests in which we replace realized equity returns with the constructed equity risk premium.

In our empirical tests, we follow Fama and French $(1992,1993)$ and study potential common factors driving the cross-sectional variation in expected equity returns. This strategy is consistent with Merton's (1974) original work, even though Merton uses a singlefactor dynamic model. To see this, note that the firm value is driven by a one-dimensional Brownian motion in Merton. Naturally, bond and equity returns inherit a single-factor dynamic structure. Crucially, though, one can also assume that firm value is driven by a multi-dimensional Brownian motion within the very framework used by Merton. This is exactly what we do - see Eqs. (A1) and (A2) in Appendix A. Because Merton's contingent claim analysis is agnostic about the nature of the process driving firm value, all of his bond pricing results will go through in our multi-factor setting. Bond and equity returns hence inherit a multi-factor structure in our extension of Merton's economy.

Noteworthy, even if we use a single-factor dynamic model for bond and equity returns in theory, we can still look for potential unconditional multi-factor specifications of bond and equity returns in practice. The reason is that a conditional single-factor model can be observationally equivalent to an unconditional multi-factor model (e.g., Cochrane (2001, p. 146148)). To wit, scaling the time-varying loadings in the conditional single-factor model or scaling the single factor itself by instruments (such as, the default premium, the term premium, or the dividend yield) will lead to a multi-factor unconditional model with fixed loadings.

The equivalence between single-factor conditional models and multi-factor unconditional 
models is illustrated, for example, in the simulations of Gomes et al. (2003). Their model is a single-factor conditional Consumption-CAPM. Yet, using simulated data generated from the model, Gomes et al. find that size and book-to-market can explain the cross-section of average returns in multi-factor unconditional specifications.

\subsection{Methodology}

Proposition 1 Let $R_{S t}^{i}$ be firm $i$ 's expected equity return, $R_{B t}^{i}$ be its expected debt return, $F_{i t}, B_{i t}$, and $S_{i t}$ be its assets, debt, and equity values at time $t$, respectively, and let $r_{t}$ be the interest rate. Then:

$$
R_{S t}^{i}-r_{t}=\left[\left(\frac{\partial S_{i t}}{\partial B_{i t}}\right)\left(\frac{B_{i t}}{S_{i t}}\right)\right]\left(R_{B t}^{i}-r_{t}\right)
$$

Proof. See Appendix A.

Proposition 1 is intuitive. Since both equity and debt are contingent claims written on the same set of productive assets, a firm's equity risk premium is naturally tied to its debt risk premium. Eq. (1) formalizes the intuition. The equity risk premium equals the debt risk premium multiplied by two coefficients. The first coefficient is the first derivative of equity with respect to debt. The second coefficient is the debt-equity ratio.

Empirically, Eq. (1) allows us to recover the expected equity risk premium using expected bond risk premium without assuming that the average realized equity return is an unbiased measure of the expected equity return. The next two propositions introduce our method of constructing expected bond risk premium, $R_{B t}^{i}-r_{t}$, from observable bond characteristics.

Proposition 2 Let $Y_{i t}$ be the yield to maturity, $H_{i t}$ be the modified duration, and $G_{i t}$ be the convexity of firm i's bond at time $t$. In the absence of tax differential between corporate bonds and Treasury bonds, the following relation holds for expected bond excess return and observable bond characteristics:

$$
R_{B t}^{i}-r_{t}=\left(Y_{i t}-r_{t}\right)-H_{i t} \frac{\mathrm{E}_{t}\left[d Y_{i t}\right]}{d t}+\frac{1}{2} G_{i t} \frac{\left(d Y_{i t}\right)^{2}}{d t}
$$

Proof. See Appendix A. 
Eq. (2) is easy to interpret. The first term on the right-hand side is the yield spread between the corporate bond and Treasury bill, which equals the expected excess return of the bond if the bond yield remains constant. The next two terms adjust for the changes in bond yield: the first order change is multiplied by modified duration and the second order change is multiplied by convexity. In essence, Eq. (2) provides a second order approximation of the bond risk premium based on the yield spread.

The next challenge is to model adequately the yield change. The extant literature is rich in models for bond yields (e.g., Merton (1974), Longstaff and Schwartz (1995), Collin-Dufresne and Goldstein (2001), and Huang and Huang (2003)). Rather than imposing a parametric model on the yield process, we focus on capturing two important empirical patterns: (i) bond value decreases in the event of default, and (ii) bond ratings generally revert to their long-run means conditional on no-default. Our objective is achieved in the next proposition.

Proposition 3 Let $\pi_{i t}$ be the expected default probability, $d Y_{i t}^{-}$be the yield change conditional on default, and $d Y_{i t}^{+}$be the yield change conditional on no-default. Then expected bond excess return is given by:

$$
R_{B t}^{i}-r_{t}=\left(Y_{i t}-r_{t}\right)+\mathrm{EDL}_{i t}+\mathrm{ERND}_{i t}
$$

where EDL denotes expected default loss rate, and is defined as:

$$
\mathrm{EDL}_{i t} \equiv \pi_{i t}\left(-H_{i t} \mathrm{E}_{t}\left[d Y_{i t}^{-}\right]+\frac{1}{2} G_{i t}\left(d Y_{i t}^{-}\right)^{2}\right) / d t<0
$$

and ERND denotes the expected return due to yield changes conditional on no-default, is defined:

$$
\mathrm{ERND}_{i t} \equiv\left(1-\pi_{i t}\right)\left(-H_{i t} \mathrm{E}_{t}\left[d Y_{i t}^{+}\right]+\frac{1}{2} G_{i t}\left(d Y_{i t}^{+}\right)^{2}\right) / d t
$$

Proof. See Appendix A.

Finally, notice that part of the yield spread of corporate bonds over Treasury bonds arises because corporate bond investors have to pay state and local taxes while Treasury bond investors do not. Hence, the component in the yield spread that is related to the tax differential should be removed from the spread if one wants to obtain a clean measure of 
the bond risk premium. Let $C_{i}$ be the coupon payment for bond $i$ and let $\tau$ be the effective state and local tax rate, then:

$$
R_{B t}^{i}-r_{t}=\left(Y_{i t}-r_{t}\right)+\mathrm{EDL}_{i t}+\mathrm{ERND}_{i t}-\mathrm{ETC}_{i t}
$$

where ETC denotes expected tax compensation, and is given by:

$$
\mathrm{ETC}_{i t}=\left[\left(1-\pi_{i t}\right) \frac{C_{i}}{B_{i t}} \frac{1}{d t}+\mathrm{EDL}_{i t}\right] \tau
$$

In Eq. (7), $\left(1-\pi_{i t}\right) \frac{C_{i}}{B_{i t}} \frac{1}{d t}$ is the coupon rate conditional on no-default. The expected default loss rate, EDL, is also included in (7) to capture the tax refund in the event of a default.

Our propositions are consistent with the valuation method in Merton (1974). In fact, because our formulations are in essence a second order Taylor expansion, the two approaches are mathematically equivalent. Merton models equity as an European call option on the underlying asset. The value of corporate debt, $B_{i t}$, which has face value $K$ and maturity $T$, is equal to $B_{i t}=D_{t}-P_{i t}$, where $D_{t}$ is the price of a risk free bond and $P_{i t}$ is a put option. The yield spread can then be calculated as $y_{i t}=\log \left(\frac{K}{B_{i t}}\right) / T-r$, a function of $\frac{F_{i t}}{K}$ and volatility $\sigma_{i}$ only. It seems as if systematic risk has no effects on the yield spread.

Notice, however, that the firm value process follows $\frac{d F_{i t}}{F_{i t}}=\mu_{i} d t+\sigma_{i} d \omega_{t}$, where $\mu_{i}$ is the instantaneous expected return of firm $i$, determined by its covariance with the stochastic discount factor. Now, consider two firms, 1 and 2, with firm 1 having a higher systematic risk and thus a higher expected return. Since firm 1's value grows faster than that of firm 2, all else equal, firm 1 will have a lower default probability. Hence, even though both firms have the same yield spread, after adjusting for the fair compensation for default risk, firm 1 has a higher component in the yield spread representing its higher systematic risk. In sum, the yield spreads, after properly adjusting for default risk and other components, are capable of identifying the cross-sectional variation of systematic risk and expected returns.

\subsection{Implementation}

This subsection details the empirical implementation of each of the components of our exante measure of expected return: (i) yield spreads $\left(R_{B t}^{i}-r_{t}\right)$; (ii) expected default loss rates 
$\left(\mathrm{EDL}_{i t}\right)$; (iii) no-default yields $\left(\mathrm{ERND}_{i t}\right)$; (iv) expected tax compensation $\left(\mathrm{ETC}_{i t}\right)$; and (v) the derivative of equity with respect to debt, $\frac{\partial S_{i t}}{\partial B_{i t}}$.

Yield Spreads, $R_{B t}^{i}-r_{t}$

We obtain firm-level bond data from the Lehman Brothers fixed income data set, which provides monthly information on corporate bonds, including price, yield, coupon, maturity, modified duration, and convexity, from January 1973 to march 1998. This data set, widely used in empirical research (e.g., Duffee (1999) and Elton et al. (2001)), covers a reasonably long period of time. Duffee provides a detailed description of the data set. We only include non-matrix prices because they represent true market quotes. As in Elton et al., we exclude bonds with maturity less than one year since these bonds' prices are less reliable. We include both callable and non-callable bond prices in an effort to retain as many bonds as possible, but our conclusions also hold when only non-callable bonds are used. Finally, we only include bonds issued by non-financial firms.

We obtain Treasury yields for all maturities from the Federal Reserve Board. Following Collin-Dufresne et al. (2001), we compute yield spreads as the corporate bond yields minus the Treasury yields with matching maturities.

\section{Expected Default Loss Rate, $\mathrm{EDL}_{i t}$}

The expected default loss rate equals the default probability times the actual default loss rate. Moody's publishes information on annual default rates sorted by bond rating from 1970 to 2001, and we use these data to construct expected default probabilities. We note that the literature on default risk typically only uses the unconditional average default probability for each rating and ignores the time variation in expected default probabilities (Elton et al. (2001) and Huang and Huang (2003)). Differently from these papers, our approach is designed to capture time variation in default probability. To do so, we use the three-year moving average default probability from year $t-2$ to $t$ as the one-year expected default probability for year $t .{ }^{4}$ For the case of Baa and lower grade bonds, if the expected default

\footnotetext{
${ }^{4}$ The choice of a three-year window is based on the observation that there are many two-year but few three-year windows without default. While we want to keep the number of years in the window as small as possible, we also want to ensure that expected default probabilities are not literally zero. We have also
} 
probability in a given year is zero, we replace it with the lowest positive expected default probability in the sample for that rating. This ensures that even in occasions of no actual default in three consecutive years, investors still anticipate positive default probabilities.

Table 1 reports the constructed expected default probabilities from 1973 to 1998 based on Moody's data. With only a few exceptions, expected default probabilities decrease with bond ratings. Noteworthy, those default probabilities are typically higher during recessions than during expansions, highlighting the systematic nature of corporate defaults. For example, in the 1990-91 recession, the expected default probability of B3 bonds exceeds 25\%, compared to only $5-8 \%$ during the late 1990 s expansion.

To construct the expected default loss rate, $\mathrm{EDL}_{i t}$, we still need default loss rates. Following Elton et al. (2001), we use the recovery rate estimates provided by Altman and Kishore (1998). Their recovery rates for bonds rated by S\&P are: $68.34 \%$ (for AAA bonds), $59.59 \%$ (AA), $60.63 \%$ (A), $49.42 \%$ (BBB), 39.05\% (BB), $37.54 \%$ (B), and $38.02 \%$ (CCC). As in Elton et al., we assume the equivalence between ratings by Moody's and S\&P (e.g., $\mathrm{Aaa}=\mathrm{AAA}, \ldots, \mathrm{Baa}=\mathrm{BBB}, \ldots, \mathrm{Caa}=\mathrm{CCC})$, and apply the same recovery rates.

We note that our calculations of expected default probability based on the three-year moving average implicitly assume that the moving average converges to the true expected default probability. Further, the recovery rates from Altman and Kishore (1998) are taken to be unconditional. Admittedly, on these two particular aspects, our approach does not depart significantly from the standard practice of replacing expected returns with average realized returns. However, since yield spreads are considerably less volatile than stock returns especially at the firm level, the focus of our study - our method is, at a minimum, still less subject to the criticisms discussed in Introduction.

experimented four other ways to capture the time varying one-year expected default probabilities: (i) using the average one-year default probability from year $t-3$ to $t-1$; (ii) using the actual default probability itself at year $t$; (iii) using the average default probability from year $t$ to $t+2$; and (iv) using the average default probability from year $t+1$ to $t+4$. Results from these alternative windows (available from the authors) have no bearing on our main conclusions. 


\section{Table 1 : Three-Year Moving Average Annual Default Probability (in Percent)}

This table reports the three-year moving average annual default rates for corporate bonds categorized by ratings, where the three-year window includes the current year and the previous two years. The table is constructed using annual default rate data from Moody's.

\begin{tabular}{|c|c|c|c|c|c|c|c|c|c|c|c|c|c|c|c|c|}
\hline Year & Aaa & Aa1 & $1 \mathrm{Aa}$ & Aa3 & A1 & A 2 & 3 & Baa1 & Baa2 & Baa3 & Ba1 & $\mathrm{Ba} 2$ & $\mathrm{Ba} 3$ & B1 & $\mathrm{B} 2$ & B3 \\
\hline 1973 & 0 & & 0 & 0 & 0 & 0 & 0 & & 0 & 0 & 0.430 & 30 & 0.430 & 4.920 & & \\
\hline 974 & 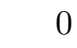 & & 0 & c & ( & & & & 0.343 & & 0.430 & & & & & \\
\hline 1975 & 0 & & 0 & 0 & 0 & & 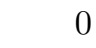 & 0.343 & 0.343 & 0.343 & 0.633 & 33 & 633 & & & \\
\hline 976 & 0 & & 0 & 0 & 0 & & & 0.280 & 0.280 & 0.280 & 0.833 & & & 4.633 & & 5.093 \\
\hline 1977 & 0 & & 0 & 0 & 0 & U & 0 & 0.280 & 0.280 & 0.280 & 0.867 & & 0.867 & & & \\
\hline 978 & 0 & & 0 & c & 0 & 0 & & 0.2 & 80 & 0.280 & 0.887 & & & 3.240 & & 3.700 \\
\hline 979 & U & & 0 & ( & 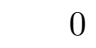 & & ( & & & & & & & & & \\
\hline 980 & 0 & & 0 & c & 0 & 0 & 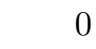 & 0.280 & 0 & 0.280 & 0.673 & 0.673 & 0. & & & 4.293 \\
\hline 981 & U & & 0 & 0 & 0 & 0 & 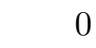 & & & & & & & & & 3.987 \\
\hline 982 & 0 & & 0 & 0 & 90 & 90 & & 0.290 & 0.290 & 90 & 1.213 & 1.213 & 1.213 & & & 3.987 \\
\hline 983 & 0 & & 0 & 0 & & & & 0. & & & 1.213 & & & & & 8.270 \\
\hline 984 & 0 & & 0 & 0 & 90 & 90 & & 0.290 & 0. & 0 & 1.457 & 1. & & 3.093 & 10. & 7.740 \\
\hline 985 & 0 & & 0 & 0 & 0 & , & 0 & 0.280 & & & 0.673 & 1.223 & & & 53 & 11.557 \\
\hline 986 & ( & & 0 & & ( & & & 0.2 & 0.2 & & 0.823 & & & & 14. & 10.943 \\
\hline 1987 & 0 & & 0 & 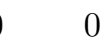 & 0 & 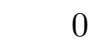 & 0 & 0.2 & 0.2 & & 1.680 & 1.260 & & 5.640 & 9.460 & 13.433 \\
\hline 1988 & ( & & 0 & & & & & & & & 1.680 & & & & & 12.053 \\
\hline 1989 & 0 & & 0 & & 0 & & ( & 0.2 & 0. & & 1.650 & 1. & & 5.170 & 6.493 & 13.213 \\
\hline 1990 & ( & & 0 & & ( & & & & & & 1.297 & & & & 12.423 & 19.400 \\
\hline 1991 & 0 & & 0 & 0.467 & 0 & & ( & 0.4 & 0.453 & & 1.507 & 1.690 & & 6.957 & 14.370 & 25.633 \\
\hline 1992 & 0 & & 0 & 0 & 0 & & & & & & & & & 5.220 & 12.123 & 27.297 \\
\hline 1993 & 0 & & 0 & & 0 & & ( & 0.4 & 0.2 & 0.2 & 0.767 & 0.430 & & 3.463 & 6.413 & 21.480 \\
\hline 1994 & 0 & & 0 & & 0 & & & & & & & & & & & 14.690 \\
\hline 1995 & 0 & & 0 & & 0 & & & 0.280 & 0.280 & 0.280 & 0.557 & 0.430 & & 3.190 & & 7.877 \\
\hline 1996 & 0 & & 0 & & 0 & & & & & & & & & & & 5.170 \\
\hline 1997 & 0 & & 0 & & . & & & & & & 0.430 & 0.430 & & 2.183 & 3.120 & 4.957 \\
\hline 1998 & 0 & & 0 & 0 & 0 & 0 & 0 & 0.280 & 0.293 & 0.280 & 0.430 & 0.490 & 0.663 & 1.443 & 3.523 & 5.460 \\
\hline
\end{tabular}

The Expected Return Due to Yield Changes Conditional on No-default, ERND ${ }_{i t}$

To calculate $\mathrm{ERND}_{i t}$, we need to calculate $d Y_{i t}^{+}$, the yield changes conditional on no-default. We first some evidence on the mean-reverting behavior of default probabilities, and then discuss our procedure of constructing $d Y_{i t}^{+}$based on the bond data.

Evidence on Mean-Reverting Default Probabilities Empirically, if a bond does not default, its default probability mean-reverts. In Table 2, we report one-year default probabilities from one to 20 years conditional on no-default in the previous year. The cohorts of bonds are sorted by their ratings in the initial year. These probabilities are constructed by 


\section{Table 2 : Annual Default Probability Conditional on No-Default in the Previous Year (in Percent)}

This table reports the annual default probability conditional on no-default in the previous year. The table is constructed using the average one-year rating transition matrix of Moody's and that of S\&P Corporation, reported in Table V of Elton et al. (2001).

\begin{tabular}{lrrrrrrr}
\hline Year & Aaa & Aa & A & Baa & Ba & B & Caa \\
\hline 1 & 0 & 0 & 0.052 & 0.158 & 1.402 & 7.403 & 22.289 \\
2 & 0.001 & 0.011 & 0.094 & 0.312 & 1.949 & 7.459 & 19.278 \\
3 & 0.004 & 0.024 & 0.139 & 0.467 & 2.348 & 7.337 & 16.427 \\
4 & 0.008 & 0.042 & 0.188 & 0.615 & 2.633 & 7.112 & 13.887 \\
5 & 0.013 & 0.062 & 0.239 & 0.752 & 2.832 & 6.830 & 11.726 \\
6 & 0.020 & 0.084 & 0.290 & 0.877 & 2.963 & 6.521 & 9.947 \\
7 & 0.029 & 0.109 & 0.343 & 0.987 & 3.044 & 6.204 & 8.511 \\
8 & 0.039 & 0.136 & 0.397 & 1.085 & 3.084 & 5.889 & 7.368 \\
9 & 0.051 & 0.165 & 0.449 & 1.169 & 3.094 & 5.585 & 6.461 \\
10 & 0.065 & 0.195 & 0.500 & 1.243 & 3.081 & 5.295 & 5.742 \\
11 & 0.080 & 0.226 & 0.550 & 1.304 & 3.051 & 5.022 & 5.169 \\
12 & 0.096 & 0.259 & 0.597 & 1.356 & 3.009 & 4.767 & 4.707 \\
13 & 0.114 & 0.291 & 0.643 & 1.399 & 2.957 & 4.528 & 4.330 \\
14 & 0.133 & 0.324 & 0.686 & 1.435 & 2.898 & 4.306 & 4.019 \\
15 & 0.153 & 0.358 & 0.727 & 1.463 & 2.837 & 4.100 & 3.758 \\
16 & 0.175 & 0.391 & 0.765 & 1.486 & 2.771 & 3.910 & 3.535 \\
17 & 0.197 & 0.425 & 0.802 & 1.503 & 2.706 & 3.733 & 3.344 \\
18 & 0.220 & 0.458 & 0.835 & 1.516 & 2.639 & 3.569 & 3.175 \\
19 & 0.243 & 0.490 & 0.867 & 1.525 & 2.574 & 3.417 & 3.027 \\
20 & 0.268 & 0.522 & 0.895 & 1.530 & 2.510 & 3.276 & 2.894 \\
\hline
\end{tabular}

using the one-year default transition matrices provided by Moody's and S\&P Corporation.

The first row of Table 2 shows that the default probability for Aaa bonds in the first year is zero, a pattern consistent with that reported in the first three columns of Table 1 . Table 2 reports positive default probabilities for Aaa bonds starting from the second year. This is also consistent with the previous table because some Aaa bonds can be downgraded and lower rated bonds have positive default probabilities.

More important, it is clear from Table 2 that, conditional on no-default, annual default probabilities increase over the years for bonds with originally high rating, but they decrease for bonds with originally low rating. For example, at year one, the one-year ahead default probability for Caa bonds is $22.28 \%$. The one-year default probability then goes down to $19.28 \%$ in the second year and to $16.43 \%$ in the third year. Since mean-reverting default probabilities imply mean-reverting yields, high-quality bonds can have positive yield spreads 


\section{Table 3 : Evolution of Ratings and Yield Spreads in Corporate Bonds}

This table uses Lehman Brothers Fixed Income data set (January 1973 to March 1998) to form cohorts of bonds with the same initial rating each year. Ratings from Aaa to Caa are assigned integer numbers from one to seven, with higher numbers indicating lower ratings. We report the average rating and yield spread changes for the same initial rating groups. Changes in yield spreads are in percent. The $t$-statistics adjusted for heteroscedasticity and autocorrelations of up to 12 monthly lags from GMM are reported in parentheses.

\begin{tabular}{ccccccccc}
\hline Year & Changes in & Aaa & Aa & A & Baa & Ba & B & Caa \\
\hline \multirow{2}{*}{1} & Rating & 0.093 & 0.087 & 0.046 & 0.017 & 0.005 & -0.045 & 0.195 \\
& & $(7.54)$ & $(14.98)$ & $(12.38)$ & $(2.91)$ & $(0.46)$ & $(-8.28)$ & $(-5.49)$ \\
& \multirow{2}{*}{ Yield Spread } & 0.084 & 0.062 & 0.079 & 0.080 & -0.024 & 0.556 & -1.402 \\
& & $(3.49)$ & $(6.27)$ & $(11.34)$ & $(5.90)$ & $(-0.75)$ & $(7.69)$ & $(-4.86)$ \\
\cline { 2 - 8 } 2 & \multirow{2}{*}{ Rating } & 0.175 & 0.181 & 0.088 & 0.047 & -0.007 & -0.114 & -0.350 \\
& & $(9.15)$ & $(16.98)$ & $(12.82)$ & $(3.87)$ & $(-0.42)$ & $(-9.39)$ & $(-6.04)$ \\
& \multirow{2}{*}{ Yield Spread } & 0.177 & 0.153 & 0.160 & 0.104 & 0.213 & 1.075 & -0.922 \\
& & $(4.55)$ & $(9.08)$ & $(10.61)$ & $(4.03)$ & $(2.93)$ & $(7.06)$ & $(-1.98)$ \\
\cline { 2 - 8 } 3 & \multirow{2}{*}{ Rating } & 0.262 & 0.264 & 0.139 & 0.082 & -0.019 & -0.166 & -0.500 \\
& & $(10.19)$ & $(18.63)$ & $(13.79)$ & $(4.49)$ & $(-0.75)$ & $(-9.40)$ & $(-6.70)$ \\
& \multirow{2}{*}{ Yield Spread } & 0.306 & 0.251 & 0.196 & 0.109 & 0.191 & 1.411 & -1.461 \\
& & $(6.21)$ & $(9.05)$ & $(11.43)$ & $(2.92)$ & $(1.87)$ & $(6.75)$ & $(-2.57)$ \\
\hline
\end{tabular}

even though their one-year default rates are close to zero.

Table 3 provides further evidence on the mean reversion of yield spreads. On an annual basis, we pool together all bonds belonging to the same Moody's rating category in the Lehman Brothers data set and study the changes in cumulative average ratings and yield spreads over the following three years. We assign numeric numbers, from one to seven, to bonds rated from Aaa to Caa, with a lower number corresponding to a better rating.

Table 3 shows that the ratings of high-quality bonds (Aaa, Aa) indeed decline over time while their yield spreads increase. For example, the rating of Aa-rated bonds, conditional on no-default, increases by 0.087 after a year, where an increase of one indicates a full downgrade to grade A. Accordingly, the average yield spread of Aa bonds increases by 6.2 basis points. In contrast, the ratings of low-quality bonds (Caa) improve over time and their yield spreads decline. The evidence clearly shows mean reversion in yield spread conditional on no-default.

Modeling Mean-Reverting Yield Changes We adopt the following three-step procedure to recover $d Y_{i t}^{+}$, the yield change conditional on no-default, from the data. First, 
we construct the cumulative default probability for each maturity using Table 2. For example, the conditional default probabilities for a bond initially rated Baa are $0.16 \%$ and $0.31 \%$ for the first two years, respectively. Assuming that the default rate is the same within a given year, the cumulative default probabilities are $0.16 \%, 0.16 \%, 0.47 \%(=0.16 \%+(1-0.16 \%) \times 0.31 \%)$, and again $0.47 \%$ for 0.5-year, 1-year, 1.5-year, and 2-year maturity, respectively.

Second, for each bond we calculate the expected cash flow, while taking into account possible default. The expected cash flow for a particular coupon date before maturity is equal to: coupon payment $\times[1-$ cumulative default probability $\times(1$ - recovery rate $)]$, where the recovery rates are from Altman and Kishore (1998). We calculate the present value of the bond by discounting its expected cash flows by the corresponding Treasury yields with matching maturities. ${ }^{5}$ After we obtain bond prices, we then calculate bond yields.

For example, suppose the bond in the previous example has two years to maturity and the coupon rate is $8 \%$ with face value of $\$ 100$. Further assume that the current Treasury yield, with annualized semi-annual compounding, is $8 \%$ for a two-year maturity. Without default, the cash flows for the bond are $\$ 4, \$ 4, \$ 4$, and $\$ 104$ for the four half-year periods. The recovery rate from Altman and Kishore (1998) for the Baa-rated bond is $49.42 \%$. With default risk, the expected cash flows are $(1-0.16 \% \times(1-49.42 \%)) \times 4,(1-0.16 \% \times(1-49.42 \%)) \times 4$, $(1-0.47 \% \times(1-49.42 \%)) \times 4$, and $(1-0.47 \% \times(1-49.42 \%)) \times 104$, respectively. The present value, when we use the discount rate of $8 \%$, is thus $\$ 99.77$. With the promised cash flows of $\$ 4, \$ 4, \$ 4$, and $\$ 104$, and the price at $\$ 99.77$, the bond yield equals $8.12 \%$.

Third, assume that the bond does not default within the first year. Conditional on that event, the bond maturity decreases by one year, and the second-year conditional default probability reported in Table 2 becomes the first-year default probability for this "new" bond. One can iterate over the last two steps to calculate the price and yield for the new bond. Because conditional default probabilities of high grade bonds will increase in the second year, bond prices will decrease and yields will increase, revealing a downgrading trend. Similarly, because conditional default probabilities will decrease for low grade bonds in the second year, bond prices will increase and yields will decrease, representing an upgrading

\footnotetext{
${ }^{5}$ This is equivalent to calculating the fair price of the bond by a risk-neutral investor.
} 
trend. The yield difference between the last two steps will be our proxy for the yield change conditional on no-default within the first year. As expected, this yield change, $d Y_{i t}^{+}$, will be positive for high grade bonds but negative for low grade bonds.

Let's again consider our numerical example. After one year, conditional on no-default, the new cumulative default rates will be $0.31 \%$ and $0.31 \%$ for the 0.5 -year and 1 -year maturities. Using our method to calculate the expected cash flows for this bond, we find the new price to be $\$ 99.85$ and the yield to be $8.17 \%$. Thus, the bond yield will go up by five basis points due to the expected increase of default probability. The five basis points will be used as $d Y_{i t}^{+}$ in calculating $\mathrm{ERND}_{i t}$, the expected return due to yield change conditional on no-default.

To sum up, ERND Et $_{i s}$ a function of rating-specific default probability, bond specific maturity, duration, convexity, and the Treasury yield for a given month. Although a bit tedious, our method ensures that this component of yield spread dynamics is captured with the best available information for the particular bond at any given time.

\section{Expected Tax Compensation, $\mathrm{ETC}_{i t}$}

To calculate the expected tax compensation given by (7), we follow Elton et al. (2001) and set the effective state and local tax rate to be $4 \%$ for all bonds. This completes our construction of the four components in the bond risk premium formula (6).

\section{Constructing Expected Equity Returns}

Armed with a measure of expected bond risk premium, it is straightforward to use Proposition 1 to obtain expected equity risk premium. Note, though, that we do not directly

observe $\frac{\partial S_{i t}}{\partial B_{i t}}$. This derivative needs to be estimated from the data and the following steps describe our estimation procedure.

First, we combine the bond data with CRSP monthly data to obtain market capitalization for equity, and then merge it further with Compustat to gather information on firm leverage. The final merged Lehman Brothers/CRSP/Compustat data set includes 1,023 non-financial firms covering the period from January 1973 to March 1998.

Second, for each firm, we calculate the change of $S_{i t}$ as the market capitalization change 
for each month. We also add together the value change for each bond within each firm. Our bond data covers approximately $50 \%$ of all debt for each Compustat-matched firm, and in order to obtain the change of $B_{i t}$, we multiply the total bond value change by the ratio of book debt from Compustat to the total bond face value from our Lehman Brothers data set.

We then obtain projected estimates for $\frac{\partial S_{i t}}{\partial B_{i t}}$ using a pooled panel regression of $\frac{\partial S_{i t}}{\partial B_{i t}}$ on a constant and the debt/equity ratio ( $t$-statistics in parentheses):

$$
\frac{\partial S_{i t}}{\partial B_{i t}}=\underset{(49.50)}{12.83}-\underset{(12.55)}{0.58} \frac{B_{i t}}{S_{i t}} .
$$

While the specification of Eq. (8) is admittedly simple, we later conduct extensive robustness checks using alternative specifications for $\frac{\partial S_{i t}}{\partial B_{i t}}$ in Section 4.4. As it turns out, the above parsimonious specification is already sufficient in delivering our main results.

The predicted negative relation between $\frac{\partial S_{i t}}{\partial B_{i t}}$ and $\frac{B_{i t}}{S_{i t}}$ agrees with theoretical priors. To see this, consider the simple model of Merton (1974), in which the equity $S$ is a European call option on the underlying asset $F$. The debt is a zero coupon bond with face value of $K$ and maturity of $T$ years. The Black and Scholes' (1973) formula implies that: $\frac{\partial S}{\partial B}=\frac{N\left(d_{1}\right)}{1-N\left(d_{1}\right)}$, where $N(\cdot)$ is the cumulative density function of normal distribution, $d_{1} \equiv \frac{\log (F / K)+\left(r+\frac{1}{2} \sigma^{2}\right) T}{\sigma \sqrt{T}}$, and $\sigma$ is the volatility of the firm's asset return. Because $d_{1}$ is always positive, $N\left(d_{1}\right)>0.5$ and $\frac{N\left(d_{1}\right)}{1-N\left(d_{1}\right)}>1$. Moreover, because $d_{1}$ decreases with $\frac{K}{F}, \frac{N\left(d_{1}\right)}{1-N\left(d_{1}\right)}$ decreases with the leverage ratio. That is, for firms with higher leverage, a unit change of debt value is associated with a smaller change in the equity value. Intuitively, given one unit of firm value change, the change in equity value will be smaller if the debt portion is larger.

Having developed empirical counterparts for each of the components of our ex-ante return measure, we substitute those estimates into Eq. (1) for each firm-month in our sample. We can now study the pricing of risky securities with a direct measure of expected returns.

\section{Empirical Findings}

We first report summary statistics of yield spreads and expected bond risk premia that are used in our expected equity return measure in Section 4.1. Section 4.2 studies the properties 
Table 4 : Descriptive Statistics of Yield Spreads and Expected Bond Risk Premium By Bond Ratings

This table reports mean, standard deviation (std), min, max, and autocorrelations of orders $1\left(\rho_{1}\right), 2\left(\rho_{2}\right)$, $6\left(\rho_{6}\right)$, and $12\left(\rho_{12}\right)$, of yield spread (Panel A) and expected bond risk premium (Panel B) for bonds rated from $\mathrm{B}$ to Aaa. The mean, std, min, and max are in annualized percent.

\begin{tabular}{|c|c|c|c|c|c|c|c|c|}
\hline \multirow[b]{2}{*}{ Rating } & \multicolumn{6}{|c|}{ Panel A: Yield Spread } & \multirow[b]{2}{*}{$\rho_{6}$} & \multirow[b]{2}{*}{$\rho_{12}$} \\
\hline & mean & std & $\min$ & $\max$ & $\rho_{1}$ & $\rho_{2}$ & & \\
\hline Aaa & 0.850 & 0.521 & 0.302 & 3.092 & 0.948 & 0.909 & 0.781 & 0.540 \\
\hline $\mathrm{Aa}$ & 0.897 & 0.342 & 0.419 & 2.286 & 0.965 & 0.930 & 0.800 & 0.616 \\
\hline A & 1.093 & 0.354 & 0.608 & 2.514 & 0.948 & 0.902 & 0.691 & 0.409 \\
\hline Baa & 1.805 & 0.638 & 0.456 & 4.310 & 0.955 & 0.910 & 0.708 & 0.445 \\
\hline $\mathrm{Ba}$ & 2.967 & 0.837 & 1.738 & 6.785 & 0.852 & 0.793 & 0.626 & 0.419 \\
\hline $\mathrm{B}$ & 5.494 & 2.373 & 2.671 & 18.460 & 0.957 & 0.932 & 0.801 & 0.546 \\
\hline \multicolumn{9}{|c|}{ Panel B: Expected Bond Risk Premium } \\
\hline Rating & mean & std & $\min$ & $\max$ & $\rho_{1}$ & $\rho_{2}$ & $\rho_{6}$ & $\rho_{12}$ \\
\hline Aaa & 0.464 & 0.488 & -0.027 & 2.653 & 0.942 & 0.897 & 0.748 & 0.470 \\
\hline $\mathrm{Aa}$ & 0.465 & 0.326 & 0.011 & 1.863 & 0.960 & 0.919 & 0.760 & 0.543 \\
\hline $\mathrm{A}$ & 0.607 & 0.330 & 0.133 & 2.045 & 0.943 & 0.891 & 0.655 & 0.351 \\
\hline Baa & 0.930 & 0.573 & -0.017 & 3.379 & 0.946 & 0.892 & 0.666 & 0.408 \\
\hline $\mathrm{Ba}$ & 1.053 & 0.547 & 0.110 & 2.917 & 0.816 & 0.722 & 0.432 & 0.107 \\
\hline B & 2.238 & 1.405 & 0.066 & 10.980 & 0.844 & 0.765 & 0.596 & 0.311 \\
\hline
\end{tabular}

of the common equity factors of Fama and French (1993) and momentum under our exante measure. Section 4.3 examines the cross-sectional variation of the expected equity risk premium. Finally, Section 4.4 tests the robustness of our basic results.

\subsection{Yield Spreads and Expected Bond Risk Premium}

Table 4 reports summary statistics of yield spreads and constructed bond risk premia for Bthrough Aaa-rated bonds. Because data are not available on time-varying default rates for bonds rated Caa or lower, we delete these bonds from the sample. (These bonds consist of about one percent of all bonds.) We construct firm-level bond risk premium as the simple average of the risk premia of all the bonds issued by the firm, but emphasize that the use of value-weighted averages yields very similar results, as different bonds issued by the same firm earn very similar risk premia.

Table 4 shows that the yield spread and the expected bond risk premium increase as the bond rating decreases. The bond risk premium for Aaa-rated bonds is on average $0.46 \%$ 
per annum, and it goes up to $2.24 \%$ for B-rated bonds. This evidence suggests that lower graded bonds are systematically riskier than higher graded bonds. Both the yield spread and the expected bond risk premium are highly persistent. The first-order autocorrelations range from 0.82 to 0.97 , and the $12^{\text {th }}$-order autocorrelations range from 0.10 to 0.60 .

\subsection{Common Factors in Expected Equity Returns}

We define the market equity risk premium as the value-weighted average equity risk premia of all firms. The expected returns of the size and book-to-market factors (SMB and HML, respectively) are constructed following exactly the procedure used by Fama and French (1993). To construct the momentum factor, we sort stocks each month on the basis of their realized equity return in the past 12 months into winners (W>70\%), medium $(70 \% \geq \mathrm{M} \geq 30 \%)$, and losers $(\mathrm{L}<30 \%)$ categories. We skip one month to avoid market microstructure difficulties and hold the portfolios for 12 months. The momentum factor is then computed as the winner-minus-loser (WML) portfolio.

\section{Descriptive Statistics}

Panel A of Table 5 reports the summary statistics of expected returns of the four common equity factors. The expected market risk premium is on average $3.93 \%$ per annum. The expected size premium is on average $5.68 \%$ and the expected value premium is on average 9.04\% . The momentum factor, in contrast, earns a negative expected return of $-2.02 \%$.

Panel B of Table 5 reports the correlation matrix of the expected returns of the four equity factors. The expected return of the market factor is positively correlated with the size factor (0.19) and the book-to-market factor (0.68), but is negatively correlated with the momentum factor $(-0.44)$. We also find that the bond market portfolio earns on average $0.42 \%$ per annum (raw standard deviation of $0.33 \%$ ). The equity market risk premium is highly positively correlated with the market bond risk premium; with a correlation coefficient of 0.86 . This is not surprising under our approach since, as contingent claims on the same productive assets, equity and bond should share similar risk factors.

Panel $\mathrm{C}$ reports the market regressions of SMB, HML, and WML. The unconditional alphas of SMB and HML are $4.41 \%$ and $3.50 \%$ per annum, and are highly significant $(t$ - 


\section{Table 5 : Descriptive Statistics of Expected Returns of Common Equity Factors}

This table reports summary statistics of expected returns of common equity factors, including market excess return (MKT), SMB, HML, and WML (the momentum factor). Panel A reports mean, standard deviation (std), min, max, and autocorrelations of orders $1\left(\rho_{1}\right), 2\left(\rho_{2}\right), 6\left(\rho_{6}\right)$, and $12\left(\rho_{12}\right)$. Panel B reports the results of market regressions for SMB, HML, and WML, including the intercepts $(\alpha)$ and the slopes $(\beta)$ as well as their $t$-statistics. And Panel $\mathrm{C}$ reports the correlation matrix for these four factors. The numbers of mean, std, min, $\max$, and $\alpha$ are in annualized percent. All cross-correlations in Panel $\mathrm{C}$ are significant at the one percent significance level. All the $t$-statistics estimated from GMM are adjusted for heteroscedasticity and autocorrelations of up to 12 lags.

\begin{tabular}{|c|c|c|c|c|c|c|c|c|}
\hline \multirow{8}{*}{$\begin{array}{l}\text { MKT } \\
\text { SMB } \\
\text { HML } \\
\text { WML }\end{array}$} & \multicolumn{8}{|c|}{ Panel A: Summary Statistics } \\
\hline & mean & std & $\min$ & $\max$ & $\rho_{1}$ & $\rho_{2}$ & $\rho_{6}$ & $\rho_{12}$ \\
\hline & 3.926 & 2.568 & 0.220 & 15.549 & 0.888 & 0.848 & 0.698 & 0.408 \\
\hline & 5.677 & 4.354 & -2.749 & 22.774 & 0.921 & 0.875 & 0.642 & 0.353 \\
\hline & 9.042 & 5.353 & -3.225 & 26.314 & 0.896 & 0.837 & 0.701 & 0.554 \\
\hline & -2.021 & 4.889 & -18.177 & 12.513 & 0.834 & 0.768 & 0.350 & 0.159 \\
\hline & \multicolumn{4}{|c|}{ Panel B: Cross-Correlations } & \multicolumn{4}{|c|}{ Panel C: Market Regressions } \\
\hline & MKT & SMB & HML & WML & $\alpha$ & $t_{\alpha}$ & $\beta$ & $t_{\beta}$ \\
\hline MKT & 1 & 0.191 & 0.677 & -0.439 & na & na & na & na \\
\hline SMB & & 1 & -0.202 & -0.209 & 4.410 & 8.599 & 0.327 & 3.062 \\
\hline HML & & & 1 & -0.274 & 3.498 & 6.925 & 1.430 & 13.894 \\
\hline WML & & & & 1 & 1.265 & 2.346 & -0.860 & -7.974 \\
\hline
\end{tabular}

statistics of 8.60 and 6.93, respectively). The unconditional betas of SMB and HML are also positive and statistically significant. WML has a positive unconditional alpha of $1.27 \%$ ( $t$-statistic of 2.35), but a negative unconditional beta of -0.86 ( $t$-statistic of -7.97).

\section{Business Cycle Properties}

We now investigate the cyclical properties of the expected returns for the four equity factors during the 1973-1998 period. Following the empirical business cycle literature (e.g., Stock and Watson (1999, Table 2)), Table 6 reports the cross correlations (with different leads and lags) of the expected returns with the cyclical component of the real industrial production index. The industrial production index is obtained from the monthly database of the Federal Reserve Bank of Saint Louis. We follow Stock and Watson (1999) by removing from the output series its long-run growth component as well as those fluctuations that occur over periods shorter than a business cycle, which arise from temporary factors such 


\section{Table 6 : Cross Correlations with Cyclical Component of Industrial Production}

This table reports the cross correlations of expected returns of equity factors with the cyclical component of the industrial production index, $\operatorname{corr}\left(r_{t}, y_{t+k}\right)$, for different leads and lags, $k$. The cyclical component of the real industrial production index (obtained from FRED) is estimated by passing the raw series through the Hodrick and Prescott (1997) filter. $p$-values of the cross correlations are reported in parentheses.

\begin{tabular}{cccccccccccccccc}
\hline \multirow{2}{*}{$r_{t}$} & \multicolumn{110}{c}{$\operatorname{corr}\left(r_{t}, y_{t+k}\right)$} \\
\cline { 2 - 14 } & -24 & -12 & -6 & -3 & -2 & -1 & 0 & 1 & 2 & 3 & 6 & 12 & 24 \\
\cline { 2 - 14 } MKT & 0.222 & 0.193 & 0.070 & -0.051 & -0.122 & -0.195 & -0.241 & -0.289 & -0.314 & -0.313 & -0.320 & -0.198 & 0.228 \\
& $(0.00)$ & $(0.00)$ & $(0.23)$ & $(0.38)$ & $(0.04)$ & $(0.00)$ & $(0.00)$ & $(0.00)$ & $(0.00)$ & $(0.00)$ & $(0.00)$ & $(0.00)$ & $(0.00)$ \\
SMB & -0.136 & 0.171 & 0.056 & -0.128 & -0.199 & -0.275 & -0.357 & -0.426 & -0.463 & -0.473 & -0.425 & -0.086 & 0.373 \\
& $(0.03)$ & $(0.01)$ & $(0.37)$ & $(0.04)$ & $(0.00)$ & $(0.00)$ & $(0.00)$ & $(0.00)$ & $(0.00)$ & $(0.00)$ & $(0.00)$ & $(0.18)$ & $(0.00)$ \\
HML & 0.145 & 0.049 & -0.044 & -0.162 & -0.222 & -0.269 & -0.295 & -0.309 & -0.308 & -0.299 & -0.227 & -0.117 & 0.154 \\
& $(0.02)$ & $(0.43)$ & $(0.48)$ & $(0.01)$ & $(0.00)$ & $(0.00)$ & $(0.00)$ & $(0.00)$ & $(0.00)$ & $(0.00)$ & $(0.00)$ & $(0.07)$ & $(0.02)$ \\
WML & -0.209 & -0.113 & 0.099 & 0.224 & 0.249 & 0.268 & 0.273 & 0.267 & 0.254 & 0.259 & 0.252 & 0.062 & -0.082 \\
& $(0.00)$ & $(0.06)$ & $(0.10)$ & $(0.00)$ & $(0.00)$ & $(0.00)$ & $(0.00)$ & $(0.00)$ & $(0.00)$ & $(0.00)$ & $(0.00)$ & $(0.31)$ & $(0.19)$ \\
\hline
\end{tabular}

as measurement errors. This is achieved by passing the raw industrial production index through the Hodrick and Prescott (1997) filter. Following Hodrick and Zhang (2001), we set the monthly smooth parameter in the Hodrick-Prescott filter to be 6,400.

Table 6 reports a number of interesting patterns. First, the expected market risk premium is negatively correlated with the cyclical component of output. The cross correlations are mostly negative and significant across different leads and lags. This evidence suggests that the expected market risk premium is countercyclical; i.e., investors demand a higher risk premium in recessions. This finding speaks to the criticism voiced by Elton (1999) that ex-post equity returns go down in recessions and thus fail to capture investors' (presumably) heightened required returns from risky assets in uncertain environments.

Second, both the expected size premium and the expected value premium are negatively correlated with the cyclical component of output. In other words, investors seem to perceive small and value stocks as riskier securities than big and growth stocks ex-ante, charging a countercyclical risk premium for holding those assets. The final noticeable feature of Table 6 concerns the cyclical properties of momentum. In contrast to other equity factors, expected momentum is strongly procyclical; the cross correlations between expected momentum returns and output are positive and significant at most leads and lags. 


\section{Average Realized Excess Returns versus Expected Risk Premia}

Since we argue that our constructed expected equity returns might provide new insights into the pricing of equities, it is important to show how different our proxy is from the average realized return. To this end, we run predictive regressions of future, realized cumulative equity factor returns onto the expected factor returns constructed from yield spreads.

Table 7 reports the results. Four different horizons are considered: six-month, 12-month, 24-month, and 36-month. We test the convergence of average realized equity returns and the constructed expected returns as follows. The null hypothesis is that the slope equals $1 / 2$ in the six-month horizon, one in the 12 -month horizon, two in the 24 -month horizon, and three in the 36-month horizon. We report the $p$-values associated with these tests.

From Panel A of Table 7, our proxy of the expected market risk premium is very close to the average market excess return in short horizons up to 12 months. From the reported $p$-values, the slope coefficient of regressing future realized returns onto the expected return is not reliably different from $1 / 2$ in the six-month horizon, and is not reliably different from one in the 12-month horizon. However, the expected-return measure diverges from the average realized returns over the longer horizons. Crucially, the null hypotheses of convergence at the two- and three-year horizons are rejected at the five percent significance level. We believe this evidence highlights the importance of time variation in return expectations and the limitations involved in the use of ex-post return averaging. In essence, since the expected market excess return varies over the long horizons, estimates of past expected returns cannot serve as the convergence targets of the average realized returns.

Panel B of Table 7 reports a more drastic divergence between the expected returns and the average realized returns of SMB. The slope coefficients of regressing the realized returns on the expected returns are negative across all horizons. The null of convergence is rejected in all cases. This suggests an explanation for why we find a significantly positive expected size premium in the 1973-1998 period while studies using realized returns typically report a weak or even negative size premium over comparable time periods. For example, Schwert (2003) reports that the alpha of Dimensional Fund Advisors Small Company Portfolio is $0.20 \%$ per month with a standard error of $0.30 \%$ per month. Based on this evidence that the 


\section{Table 7 : Regressing Realized Equity Factor Returns onto Their Constructed Expected Returns}

This table reports predictive regressions of realized equity factor returns including market excess return (Panel A), SMB (Panel B), HML (Panel C), and WML (Panel D) onto their respective constructed expected returns. Four different predictive horizons are considered: (i) six-month; (ii) 12-month; (iii) 24-month; and (iv) 36-month horizons. We report and slope coefficients and $R^{2}$ 's. We also test the convergence of average realized equity returns and the constructed expected returns as follows. The null hypothesis is that the slope equals $1 / 2$ for the regressions with the six-month horizon, the slope equals one for the 12 -month horizon, two for the 24-month horizon, and three for the 36-month horizon. We report the $p$-values in the parentheses for these tests. And all the $p$-values are computed using standard errors estimated from GMM and adjusted for heteroscedasticity and autocorrelations of up to 12 lags.

\begin{tabular}{|c|c|c|c|c|c|c|c|c|c|}
\hline \multicolumn{5}{|c|}{ Panel A: MKT } & \multicolumn{5}{|c|}{ Panel B: SMB } \\
\hline & 6-month & 12-month & 24-month & 36-month & & 6-month & 12-month & 24-month & 36-month \\
\hline slope & $\begin{array}{r}0.508 \\
(0.99)\end{array}$ & $\begin{array}{r}0.838 \\
(0.80)\end{array}$ & $\begin{array}{r}0.050 \\
(0.02)\end{array}$ & $\begin{array}{r}0.674 \\
(0.01)\end{array}$ & slope & $\begin{array}{r}-0.024 \\
(0.00)\end{array}$ & $\begin{array}{r}-0.139 \\
(0.00)\end{array}$ & $\begin{array}{r}-0.312 \\
(0.00)\end{array}$ & $\begin{array}{c}-0.274 \\
(0.00)\end{array}$ \\
\hline $\begin{array}{l}p \\
R^{2}\end{array}$ & $\begin{array}{r}(0.99) \\
0.014\end{array}$ & $\begin{array}{r}(0.80) \\
0.023\end{array}$ & $\begin{array}{r}(0.02) \\
0.000\end{array}$ & $\begin{array}{r}(0.01) \\
0.009\end{array}$ & $\begin{array}{l}p \\
R^{2}\end{array}$ & $\begin{array}{r}(0.00) \\
0.000\end{array}$ & $\begin{array}{r}(0.00) \\
0.007\end{array}$ & $\begin{array}{r}(0.00) \\
0.023\end{array}$ & $\begin{array}{r}0.00) \\
0.016\end{array}$ \\
\hline \multicolumn{5}{|c|}{ Panel C: HML } & \multicolumn{5}{|c|}{ Panel D: WML } \\
\hline & 6-month & 12-month & 24-month & 36-month & & 6-month & 12-month & 24-month & 36-month \\
\hline slope & 0.100 & 0.169 & 0.498 & 0.406 & slope & 0.634 & 0.825 & 0.930 & 0.474 \\
\hline$p$ & $(0.02)$ & $(0.00)$ & $(0.00)$ & $(0.00)$ & $p$ & $(0.50)$ & $(0.54)$ & $(0.00)$ & $(0.00)$ \\
\hline$R^{2}$ & 0.005 & 0.007 & 0.028 & 0.013 & $R^{2}$ & 0.096 & 0.097 & 0.104 & 0.039 \\
\hline
\end{tabular}

size premium has weakened or disappeared after its discovery by Banz (1981), Schwert argues that the size anomaly is "more apparent than real." Our evidence, however, suggests that the disappearance of the size effect could result from the high volatility of realized returns. In particular, our estimate of the SMB alpha, $4.41 \%$ per annum or $0.37 \%$ per month, is well within the one-standard-error bound estimated by Schwert.

\subsection{The Cross-Section of Expected Equity Returns}

We now examine the cross-sectional variation of expected equity returns. Using the Fama and MacBeth (1973) methodology, we study whether the factor loadings on the market beta, size, book-to-market, and momentum have explanatory power in the cross-section of expected returns. Both covariances and characteristics are used in our asset pricing tests. 


\section{Covariance-Based Tests}

Our covariance-based tests are conducted in two steps. In the first step, for each individual stock and month, we run the time series regression of the equity returns in the past 60 months (with at least 24 months of data available):

$$
r_{t+1}^{i}=\alpha_{i t}+\beta_{\mathrm{MKT}, t}^{i} \mathrm{MKT}_{t+1}+\beta_{\mathrm{SMB}, t}^{i} \mathrm{SMB}_{t+1}+\beta_{\mathrm{HML}, t}^{i} \mathrm{HML}_{t+1}+\beta_{\mathrm{WML}, t}^{i} \mathrm{WML}_{t+1}+\varepsilon_{i t+1} .
$$

where $r_{t+1}^{i}$ is the realized excess equity return of stock $i$ from time $t$ to $t+1$ over the onemonth Treasury bill rate, and MKT, SMB, HML, and WML are the excess return factors of market, size, book-to-market, and momentum taken from Kenneth French's website.

Following standard practice, we estimate the factor loadings in Eq. (9) using the realized returns of $r_{t+1}^{i}$ and the four factors. For comparison, we also estimate the loadings using our constructed expected equity returns and the expected factor premia, all dated at time

$t$. The resultant loadings are denoted $\widetilde{\beta}_{\mathrm{MKT}, t}, \widetilde{\beta}_{\mathrm{SMB}, t}, \widetilde{\beta}_{\mathrm{HML}, t}$, and $\widetilde{\beta}_{\mathrm{WML}, t}$.

In the second step, we run cross-sectional regressions, month by month, of firm-specific, expected equity returns on the factor loadings estimated from Eq.(9). The time series average of the coefficients are regarded as the risk premia associated with the loadings. We use GMM to adjust the standard errors of the coefficients for heteroscedasticity and autocorrelations of up to 12 lags. The standard errors of the intercepts are then used to compute the $t$-statistics.

The null hypothesis in our cross-sectional tests is the CAPM. We also use size, bookto-market, and prior returns to test for model misspecifications. In doing so, we implicitly assume that our constructed risk premia are unbiased measures of the true risk premia. In other words, the measurement errors in the risk premia have a mean of zero - if there were no measurement errors, then under the null hypothesis the regression $R^{2}$ should be one.

Panel A of Table 8 reports the cross-sectional regressions with the factor loadings. The column denoted Model 1 shows that when the market beta estimated with the realized returns is used alone, the slope coefficient is a positive $2.16 \%$ per annum and is highly significant. Using the market beta estimated with the expected returns reduces the slope to $0.96 \%$, but it remains significant (Model 4). Thus, stocks with higher market betas will have higher 
expected excess return, consistent with standard asset pricing models.

From Model 2 in Panel A, when the loadings on SMB and HML are also included, all three Fama-French factors have positive and significant slopes. In particular, the market beta is priced even in the presence of SMB and HML loadings, but the risk premium associated with the market beta shrinks to $0.89 \%$ per annum. From Model 3, the risk premia of the SMB and HML loadings remain positive and significant when the momentum factor is controlled for. But the risk premium of the market beta is insignificant, albeit still positive. From Models 5 and 6, using the loadings estimated with the expected returns yields stronger pricing results for the market beta. Its slope is $2.41 \%$ in the three-factor regression, and is $2.58 \%$ in the four-factor regression. Both are significant.

Panel A also shows that the HML loading is reliably priced. This result is robust to different model specifications and to different estimation methods of the factor loadings.

Finally, the cross-sectional $R^{2}$ 's range from $1.3 \%$ to $38.8 \%$. We note that although these $R^{2}$ 's are lower than those reported by Fama and French $(1993,1996)$ on the portfolio-level data, they are generally higher than those from similar cross-sectional regressions on the firm-level data. ${ }^{6}$ The reason is that our constructed expected returns are less volatile than both the realized equity returns and the realized growth rates.

\section{Characteristic-Based Tests}

In Panel B of Table 8, we retain the loading on the market factor, but replace the other loadings with firm characteristics. That is, we use the logarithm of size, the book-to-market ratio, and the prior equity return to replace their respective factor loadings. From Model 7, the market beta estimated with the realized returns is again significantly priced but the magnitude of its premium is only $1.12 \%$ per annum. Size has a negative and highly significant premium, $-4.18 \%$, and book-to-market has a positive and highly significant premium, $4.78 \%$. Using the market beta estimated with the expected returns reduces its premium to $0.53 \%$, which is only marginally significant. However, the pricing results on size and book-to-market

\footnotetext{
${ }^{6}$ For example, Chan et al. (2003, Table X) regress the growth rates of operating performance on an exhaustive list of explanatory variables. Their highest $R^{2}$ is $11.75 \%$, and most $R^{2}$ s are below $5 \%$.
} 


\section{Table 8 : The Cross-Section of Expected Equity Risk Premium}

Panel A of this table reports the Fama-MacBeth cross-sectional regressions of firm-level equity risk premium on the market beta, SMB beta, HML beta, and WML beta, separately and jointly. We estimate these betas using 60-month (or at least 24-month) rolling regressions of the realized equity excess returns onto the realized excess returns of Fama-French three factors and WML. These betas estimated from realized returns are denoted $\beta_{\mathrm{MKT}}, \beta_{\mathrm{SMB}}, \beta_{\mathrm{HML}}$, and $\beta_{\mathrm{WML}}$. We also estimate the betas from 60 -month (or at least 24-month) rolling regressions of the constructed expected excess returns onto the constructed expected Fama-French three factors and WML. These betas are denoted $\widetilde{\beta}_{\mathrm{MKT}}, \widetilde{\beta}_{\mathrm{SMB}}, \widetilde{\beta}_{\mathrm{HML}}$, and $\widetilde{\beta}_{\mathrm{WML}}$. Panel B reports the cross-sectional regressions of firm-level equity risk premium on the market beta (estimated both from the realized and the constructed expected excess returns), size, book-to-market, and past 12-month returns, separately and jointly. The $t$-statistics reported in parentheses are adjusted for heteroscedasticity and autocorrelations of up to 12 lags, and are estimated with GMM. The point estimates of the intercepts and slopes are in annualized percent.

\begin{tabular}{|c|c|c|c|c|c|c|}
\hline \multicolumn{4}{|c|}{ Panel A: Covariance-Based Tests } & \multicolumn{3}{|c|}{ Panel B: Characteristic-Based Tests } \\
\hline & Model 1 & Model 2 & Model 3 & & Model 7 & Model 8 \\
\hline Intercept & $\begin{array}{r}5.675 \\
(10.17)\end{array}$ & $\begin{array}{r}5.449 \\
(11.20)\end{array}$ & $\begin{array}{r}5.828 \\
(10.65)\end{array}$ & Intercept & $\begin{array}{c}31.965 \\
(18.60)\end{array}$ & $\begin{array}{r}32.220 \\
(18.86)\end{array}$ \\
\hline$\beta_{\mathrm{MKT}}$ & $\begin{array}{r}2.159 \\
(5.45)\end{array}$ & $\begin{array}{r}0.894 \\
(2.03)\end{array}$ & $\begin{array}{r}0.714 \\
(1.49)\end{array}$ & $\beta_{\mathrm{MKT}}$ & $\begin{array}{l}1.124 \\
(3.59)\end{array}$ & $\begin{array}{r}1.109 \\
(4.03)\end{array}$ \\
\hline$\beta_{\mathrm{SMB}}$ & & $\begin{array}{r}4.806 \\
(13.59)\end{array}$ & $\begin{array}{r}5.080 \\
(13.62)\end{array}$ & $\log (\mathrm{ME})$ & $\begin{array}{r}-4.177 \\
(-20.36)\end{array}$ & $\begin{array}{r}-4.069 \\
(-20.36)\end{array}$ \\
\hline$\beta_{\mathrm{HML}}$ & & $\begin{array}{r}2.820 \\
(6.81)\end{array}$ & $\begin{array}{r}3.500 \\
(8.25)\end{array}$ & $\mathrm{BE} / \mathrm{ME}$ & $\begin{array}{r}4.781 \\
(7.86)\end{array}$ & $\begin{array}{l}4.388 \\
(7.87)\end{array}$ \\
\hline$\beta_{\mathrm{WML}}$ & & & $\begin{array}{r}-49.445 \\
(-0.67)\end{array}$ & Past Returns & & $\begin{array}{l}-6.206 \\
(-8.35)\end{array}$ \\
\hline \multirow[t]{2}{*}{ Average $R^{2}$} & 0.013 & 0.162 & 0.184 & Average $R^{2}$ & 0.350 & 0.370 \\
\hline & Model 4 & Model 5 & Model 6 & & Model 9 & Model 10 \\
\hline Intercept & $\begin{array}{r}8.192 \\
(14.80)\end{array}$ & $\begin{array}{r}5.787 \\
(15.31)\end{array}$ & $\begin{array}{r}5.208 \\
(16.38)\end{array}$ & Intercept & $\begin{array}{l}26.505 \\
(11.46)\end{array}$ & $\begin{array}{r}26.250 \\
(11.54)\end{array}$ \\
\hline$\widetilde{\beta}_{\mathrm{MKT}}$ & $\begin{array}{r}0.958 \\
(2.72)\end{array}$ & $\begin{array}{r}2.409 \\
(5.18)\end{array}$ & $\begin{array}{r}2.579 \\
(5.33)\end{array}$ & $\widetilde{\beta}_{\mathrm{MKT}}$ & $\begin{array}{r}0.525 \\
(1.76)\end{array}$ & $\begin{array}{r}0.543 \\
(1.88)\end{array}$ \\
\hline$\widetilde{\beta}_{\mathrm{SMB}}$ & & $\begin{array}{r}0.910 \\
(1.61)\end{array}$ & $\begin{array}{l}1.207 \\
(1.82)\end{array}$ & $\log (\mathrm{ME})$ & $\begin{array}{r}-3.153 \\
(-11.30)\end{array}$ & $\begin{array}{r}-2.984 \\
(-11.12)\end{array}$ \\
\hline$\widetilde{\beta}_{\mathrm{HML}}$ & & $\begin{array}{l}4.386 \\
(3.69)\end{array}$ & $\begin{array}{r}4.750 \\
(4.00)\end{array}$ & $\mathrm{BE} / \mathrm{ME}$ & $\begin{array}{r}5.737 \\
(8.85)\end{array}$ & $\begin{array}{l}5.276 \\
(8.69)\end{array}$ \\
\hline$\widetilde{\beta}_{\mathrm{WML}}$ & & & $\begin{array}{l}-3.312 \\
(-2.84)\end{array}$ & Past Returns & & $\begin{array}{l}-5.404 \\
(-5.51)\end{array}$ \\
\hline Average $R^{2}$ & 0.123 & 0.328 & 0.388 & Average $R^{2}$ & 0.353 & 0.370 \\
\hline
\end{tabular}


are the same. Finally, the last column of the table shows that adding post returns in the regressions does not materially change the results from the three-factor regressions.

\subsection{Robustness}

Our benchmark results on expected returns are based on Eq. (8), which specifies $\frac{\partial S_{i t}}{\partial B_{i t}}$ as a linear function of the leverage ratio, $\frac{B_{i t}}{S_{i t}}$. This specification is admittedly simple, but provides a natural starting point. For robustness, we conduct tests that use alternative specifications of $\frac{\partial S_{i t}}{\partial B_{i t}}$. In doing so, we revisit all of our results on equity pricing.

Merton (1974) implies that $\frac{\partial S}{\partial B}=\frac{N\left(d_{1}\right)}{1-N\left(d_{1}\right)}$, where $N(\cdot)$ is the cumulative distribution function of a normal variate, $d_{1} \equiv \frac{\log (F / B)+\left(r+\frac{1}{2} \sigma^{2}\right) T}{\sigma \sqrt{T}}$, and $\sigma$ is the volatility of the firm's asset return. This model suggests that $\frac{\partial S_{i t}}{\partial B_{i t}}$ should also be a function of firm volatility and the risk free rate $r_{t}$, in addition to the leverage ratio. We therefore use an alternative specification of $\frac{\partial S_{i t}}{\partial B_{i t}}$ as follows (with point estimates and their $t$-statistics reported):

$$
\frac{\partial S_{i t}}{\partial B_{i t}}=\underset{(29.7)}{23.08}+\underset{(19.06)}{2.07} \frac{B_{i t}}{S_{i t}}+\underset{(2.24)}{12.56} \sigma_{i t}-\underset{(15.27)}{1.39} r_{t}+\varepsilon_{i t}
$$

We use equity volatility instead of firm volatility (as the leverage ratio is already included).

As a less model-dependent, but more inclusive specification, we also model $\frac{\partial S_{i t}}{\partial B_{i t}}$ by augmenting Eq. (10) with the $\log$ of market value, $\log \left(\mathrm{ME}_{i t}\right)$, the book-to-market ratio, $\frac{\mathrm{BE}_{i t}}{\mathrm{ME}_{i t}}$, and the past 12-month equity return, $r_{i t}^{12}$ :

$$
\begin{aligned}
\frac{\partial S_{i t}}{\partial B_{i t}}=\underset{(-6.01)}{-11.80}-\underset{(1.04)}{0.15} \frac{B_{i t}}{S_{i t}}+\underset{(7.96)}{47.35} \sigma_{i t}-\underset{(6.38)}{0.62} r_{t} \\
\quad+\underset{(20.49)}{3.99} \log \left(\mathrm{ME}_{i t}\right)-\underset{(10.56)}{6.26} \frac{\mathrm{BE}_{i t}}{\mathrm{ME}_{i t}}+\underset{(6.18)}{5.55} r_{i t}^{12}+\varepsilon_{i t}
\end{aligned}
$$

We have also experimented with the inclusion of the yield spread in the right-hand side of Eq. (11). The reason is that $\frac{\partial S_{i t}}{\partial B_{i t}}$ is an endogenous variable, potentially depending on financing conditions captured by the yield spread. But the estimated slope of the yield spread turned out small and insignificant. Accordingly, the pricing results are fairly similar to those returned from Eq. (11) (available from the authors). ${ }^{7}$

\footnotetext{
${ }^{7}$ We thank our referee for suggesting various robustness checks.
} 
Table 9 reports the properties of the common equity factors that are constructed under the alternative proxies for $\frac{\partial S_{i t}}{\partial B_{i t}}$ from Eqs. (10) and (11); see Panels A and B, respectively. The results are largely consistent with those of Table 5. We continue to find significantly positive premia for the market and value factors. The size premium is significantly positive with specification (10), but is insignificant with (11), albeit still positive.

Table 10 reports the cross correlations of the expected equity factors with the cyclical component of the real industrial production index. Panels $\mathrm{A}$ and $\mathrm{B}$ report the results with $\frac{\partial S_{i t}}{\partial B_{i t}}$ given by Eqs. (10) and (11), respectively. From Panel A, the results are largely unchanged from Table 6 as the expected market, size, and value premia are all countercyclical and the expected momentum return is procyclical. And from Panel B, when $\frac{\partial S_{i t}}{\partial B_{i t}}$ is modelled as Eq. (11), the expected market and value premia continue to exhibit strong countercyclical movements. However, the expected size and momentum returns are both acyclical. One possible interpretation is that the additional regressors in Eq. (11) may have introduced extra noise into Eq. (10). ${ }^{8}$

Table 11 reports the cross-sectional regressions of expected equity returns on factor loadings and firm characteristics using the two alternative specifications of $\frac{\partial S_{i t}}{\partial B_{i t}}$. The results are very similar to those in Table 8 . Notice that the pricing results of the market beta are slightly stronger than those reported in Table 8. In particular, the slopes of the market betas are positive and significant across all specifications. Further, the risk premia of the HML loadings and the slopes of book-to-market are all significant and positive.

\section{Summary and Interpretation}

We construct measures of expected returns using bond yield spreads. The basic idea is simple: because both equity and bond are contingent claims written on the same productive assets (e.g., Merton (1974)), they must share the same systematic risk factors. We then use the ex-ante returns to study the cross-section of expected equity returns. Differently from the standard approach, our asset pricing tests do not assume that average realized returns

\footnotetext{
${ }^{8}$ Those additional regressors are not directly related to the partial derivative of the equity value with respect to the bond value, as predicted by Merton (1974).
} 


\section{Table 9 : Expected Returns of Common Equity Factors: Robustness Checks}

This table reports summary statistics of expected returns of common equity factors, including market excess return (MKT), SMB, HML, and WML (the momentum factor). We report mean, standard deviation (std), min, max, and autocorrelations of orders $1\left(\rho_{1}\right), 2\left(\rho_{2}\right), 6\left(\rho_{6}\right)$, and $12\left(\rho_{12}\right)$, the results of market regressions including the intercepts $(\alpha)$ and the slopes $(\beta)$ as well as their $t$-statistics and the correlation matrix for these four factors. The numbers of mean, std, min, max, and $\alpha$ are in annualized percent. All cross-correlations are significant at the 1-percent test level or lower. All the $t$-statistics are adjusted for heteroscedasticity and autocorrelations of up to 12 lags, and are estimated from GMM. Expected returns are constructed using two alternative specifications of $\frac{\partial S_{i t}}{\partial B_{i t}}$.

\begin{tabular}{|c|c|c|c|c|c|c|c|c|}
\hline \multicolumn{9}{|c|}{ Panel A: $\frac{\partial S_{i t}}{\partial B_{i t}}=\alpha_{0}+\alpha_{1} \frac{B_{i t}}{S_{i t}}+\alpha_{2} \sigma_{i t}+\alpha_{3} r_{t}+\varepsilon_{i t}$} \\
\hline & mean & std & $\min$ & $\max$ & $\rho_{1}$ & $\rho_{2}$ & $\rho_{6}$ & $\rho_{12}$ \\
\hline MKT & 4.369 & 2.520 & 0.535 & 12.348 & 0.876 & 0.794 & 0.490 & 0.329 \\
\hline SMB & 4.381 & 3.551 & -6.376 & 20.021 & 0.816 & 0.649 & 0.328 & -0.052 \\
\hline HML & 7.764 & 5.414 & -9.283 & 22.943 & 0.895 & 0.830 & 0.590 & 0.439 \\
\hline \multirow[t]{3}{*}{ WML } & -1.472 & 5.131 & -19.746 & 22.007 & 0.820 & 0.701 & 0.347 & 0.146 \\
\hline & \multicolumn{4}{|c|}{ Cross-Correlations } & \multicolumn{4}{|c|}{ Market Regressions } \\
\hline & MKT & SMB & HML & WML & $\alpha$ & $t_{\alpha}$ & $\beta$ & $t_{\beta}$ \\
\hline MKT & 1 & 0.354 & 0.558 & -0.308 & na & na & na & na \\
\hline SMB & & 1 & -0.110 & -0.263 & 2.263 & 2.600 & 0.483 & 2.062 \\
\hline HML & & & 1 & -0.164 & 2.671 & 2.720 & 1.163 & 5.139 \\
\hline WML & & & & 1 & 1.268 & 1.192 & -0.627 & -2.138 \\
\hline \multicolumn{9}{|c|}{ Panel B: $\frac{\partial S_{i t}}{\partial B_{i t}}=\alpha_{0}+\alpha_{1} \frac{B_{i t}}{S_{i t}}+\alpha_{2} \sigma_{i t}+\alpha_{3} r_{t}+\alpha_{4} \log \left(\mathrm{ME}_{i t}\right)+\alpha_{5} \frac{\mathrm{BE}_{i t}}{\mathrm{ME}_{i t}}+\alpha_{6} r_{i t}^{12}+\varepsilon_{i t}$} \\
\hline & mean & std & $\min$ & $\max$ & $\rho_{1}$ & $\rho_{2}$ & $\rho_{6}$ & $\rho_{12}$ \\
\hline MKT & 5.117 & 3.285 & 1.731 & 15.557 & 0.940 & 0.896 & 0.693 & 0.503 \\
\hline SMB & 0.101 & 2.598 & -8.123 & 8.629 & 0.762 & 0.603 & 0.332 & 0.121 \\
\hline HML & 7.650 & 6.089 & -2.556 & 26.269 & 0.903 & 0.853 & 0.740 & 0.560 \\
\hline \multirow[t]{3}{*}{ WML } & -0.723 & 4.964 & -18.849 & 12.004 & 0.771 & 0.705 & 0.298 & 0.116 \\
\hline & \multicolumn{4}{|c|}{ Cross-Correlations } & \multicolumn{4}{|c|}{ Market Regressions } \\
\hline & MKT & $\mathrm{SMB}$ & HML & WML & $\alpha$ & $t_{\alpha}$ & $\beta$ & $t_{\beta}$ \\
\hline MKT & 1 & -0.499 & 0.689 & -0.346 & na & na & na & na \\
\hline SMB & & 1 & -0.475 & 0.077 & 2.179 & 4.393 & -0.389 & -4.679 \\
\hline HML & & & 1 & -0.243 & 0.926 & 0.950 & 1.259 & 7.856 \\
\hline WML & & & & 1 & 1.949 & 2.168 & -0.522 & -2.575 \\
\hline
\end{tabular}




\section{Table 10 : Cross Correlations with Cyclical Component of Industrial Production: Robustness Checks}

This table reports the cross correlations of expected returns of equity factors with the cyclical component of the industrial production index, $\operatorname{corr}\left(r_{t}, y_{t+k}\right)$, for different leads and lags, $k$. The cyclical component of the real industrial production index (obtained from FRED) is estimated by passing the raw series through the Hodrick and Prescott (1997) filter. Expected returns are constructed using two alternative specifications of $\frac{\partial S_{i t}}{\partial B_{i t}}$. $p$-values of the cross-correlations are reported in parentheses.

\begin{tabular}{|c|c|c|c|c|c|c|c|c|c|c|c|c|c|}
\hline \multicolumn{14}{|c|}{ Panel A: $\frac{\partial S_{i t}}{\partial B_{i t}}=\alpha_{0}+\alpha_{1} \frac{B_{i t}}{S_{i t}}+\alpha_{2} \sigma_{i t}+\alpha_{3} r_{t}+\varepsilon_{i t}$} \\
\hline$k$ & -24 & -12 & -6 & -3 & -2 & -1 & 0 & 1 & 2 & 3 & 6 & 12 & 24 \\
\hline MKT & $\begin{array}{r}0.132 \\
(0.03)\end{array}$ & $\begin{array}{r}0.062 \\
(0.31)\end{array}$ & $\begin{array}{r}-0.091 \\
(0.13)\end{array}$ & $\begin{array}{c}-0.224 \\
(0.00)\end{array}$ & $\begin{array}{r}-0.299 \\
(0.00)\end{array}$ & $\begin{array}{c}-0.361 \\
(0.00)\end{array}$ & $\begin{array}{r}-0.372 \\
(0.00)\end{array}$ & $\begin{array}{r}-0.372 \\
(0.00)\end{array}$ & $\begin{array}{c}-0.344 \\
(0.00)\end{array}$ & $\begin{array}{r}-0.300 \\
(0.00)\end{array}$ & $\begin{array}{r}-0.139 \\
(0.02)\end{array}$ & $\begin{array}{r}0.135 \\
(0.03)\end{array}$ & $\begin{array}{c}0.234 \\
(0.00)\end{array}$ \\
\hline SMB & $\begin{array}{r}-0.117 \\
(0.06)\end{array}$ & $\begin{array}{r}-0.003 \\
(0.97)\end{array}$ & $\begin{array}{c}-0.215 \\
(0.00)\end{array}$ & $\begin{array}{r}-0.341 \\
(0.00)\end{array}$ & $\begin{array}{r}-0.362 \\
(0.00)\end{array}$ & $\begin{array}{r}-0.373 \\
(0.00)\end{array}$ & $\begin{array}{c}-0.392 \\
(0.00)\end{array}$ & $\begin{array}{c}-0.403 \\
(0.00)\end{array}$ & $\begin{array}{r}-0.380 \\
(0.00)\end{array}$ & $\begin{array}{c}-0.336 \\
(0.00)\end{array}$ & $\begin{array}{c}-0.161 \\
(0.01)\end{array}$ & $\begin{array}{r}0.236 \\
(0.00)\end{array}$ & $\begin{array}{r}0.270 \\
(0.00)\end{array}$ \\
\hline HML & & $\begin{array}{r}-0.032 \\
(0.61)\end{array}$ & $\begin{array}{c}-0.083 \\
(0.18)\end{array}$ & $\begin{array}{r}-0.249 \\
(0.00)\end{array}$ & $\begin{array}{r}-0.300 \\
(0.00)\end{array}$ & $\begin{array}{r}-0.319 \\
(0.00)\end{array}$ & $\begin{array}{c}-0.322 \\
(0.00)\end{array}$ & $\begin{array}{r}-0.307 \\
(0.00)\end{array}$ & $\begin{array}{c}-0.274 \\
(0.00)\end{array}$ & $\begin{array}{c}-0.234 \\
(0.00)\end{array}$ & $\begin{array}{r}-0.109 \\
(0.08)\end{array}$ & $\begin{array}{r}0.053 \\
(0.41)\end{array}$ & \\
\hline $\mathrm{WM}$ & $\begin{array}{r}-0.348 \\
(0.00)\end{array}$ & $\begin{array}{r}-0.200 \\
(0.00)\end{array}$ & $\begin{array}{r}-0.071 \\
(0.24)\end{array}$ & $\begin{array}{r}0.120 \\
(0.04)\end{array}$ & $\begin{array}{r}0.201 \\
(0.00) \\
\end{array}$ & $\begin{array}{r}0.255 \\
(0.00)\end{array}$ & $\begin{array}{r}0.259 \\
(0.00) \\
\end{array}$ & $\begin{array}{r}0.269 \\
(0.00) \\
\end{array}$ & $\begin{array}{r}0.251 \\
(0.00)\end{array}$ & $\begin{array}{r}0.233 \\
(0.00)\end{array}$ & $\begin{array}{r}0.170 \\
(0.01)\end{array}$ & $\begin{array}{r}0.001 \\
(0.98) \\
\end{array}$ & $\begin{array}{r}-0.021 \\
(0.73)\end{array}$ \\
\hline \multicolumn{14}{|c|}{ Panel B: $\frac{\partial S_{i t}}{\partial B_{i t}}=\alpha_{0}+\alpha_{1} \frac{B_{i t}}{S_{i t}}+\alpha_{2} \sigma_{i t}+\alpha_{3} r_{t}+\alpha_{4} \log \left(\mathrm{ME}_{i t}\right)+\alpha_{5} \frac{\mathrm{BE}_{i t}}{\mathrm{ME}_{i t}}+\alpha_{6} r_{i t}^{12}+\varepsilon_{i t}$} \\
\hline$k$ & -24 & -12 & -6 & -3 & -2 & -1 & 0 & 1 & 2 & 3 & 6 & 12 & 24 \\
\hline MKT & $\begin{array}{r}0.310 \\
(0.00)\end{array}$ & $\begin{array}{r}0.116 \\
(0.06)\end{array}$ & $\begin{array}{c}-0.080 \\
(0.19)\end{array}$ & $\begin{array}{c}-0.181 \\
(0.00)\end{array}$ & $\begin{array}{r}-0.229 \\
(0.00)\end{array}$ & $\begin{array}{r}-0.270 \\
(0.00)\end{array}$ & $\begin{array}{r}-0.283 \\
(0.00)\end{array}$ & $\begin{array}{c}-0.288 \\
(0.00)\end{array}$ & $\begin{array}{c}-0.274 \\
(0.00)\end{array}$ & $\begin{array}{c}-0.245 \\
(0.00)\end{array}$ & $\begin{array}{c}-0.144 \\
(0.02)\end{array}$ & $\begin{array}{r}0.009 \\
(0.89)\end{array}$ & $\begin{array}{r}0.230 \\
(0.00)\end{array}$ \\
\hline SMB & $\begin{array}{r}-0.212 \\
(0.00)\end{array}$ & $\begin{array}{c}-0.094 \\
(0.13)\end{array}$ & $\begin{array}{r}0.055 \\
(0.38)\end{array}$ & $\begin{array}{r}0.068 \\
(0.28)\end{array}$ & $\begin{array}{r}0.093 \\
(0.14)\end{array}$ & $\begin{array}{r}0.110 \\
(0.08)\end{array}$ & $\begin{array}{c}0.095 \\
(0.13)\end{array}$ & $\begin{array}{c}0.064 \\
(0.31)\end{array}$ & $\begin{array}{c}0.031 \\
(0.62)\end{array}$ & $\begin{array}{r}0.010 \\
(0.87)\end{array}$ & $\begin{array}{r}-0.029 \\
(0.65)\end{array}$ & $\begin{array}{r}0.011 \\
(0.87)\end{array}$ & $\begin{array}{c}0.022 \\
(0.74)\end{array}$ \\
\hline HML & $\begin{array}{r}0.168 \\
(0.01)\end{array}$ & $\begin{array}{r}0.018 \\
(0.77)\end{array}$ & $\begin{array}{c}-0.171 \\
(0.01)\end{array}$ & $\begin{array}{c}-0.214 \\
(0.00)\end{array}$ & $\begin{array}{c}-0.234 \\
(0.00)\end{array}$ & $\begin{array}{r}-0.240 \\
(0.00)\end{array}$ & $\begin{array}{c}-0.239 \\
(0.00)\end{array}$ & $\begin{array}{r}-0.237 \\
(0.00)\end{array}$ & $\begin{array}{c}-0.236 \\
(0.00)\end{array}$ & $\begin{array}{c}-0.232 \\
(0.00)\end{array}$ & $\begin{array}{c}-0.181 \\
(0.00)\end{array}$ & $\begin{array}{r}0.007 \\
(0.91)\end{array}$ & $\begin{array}{r}0.120 \\
(0.07)\end{array}$ \\
\hline WML & $\begin{array}{r}-0.354 \\
(0.00) \\
\end{array}$ & $\begin{array}{r}0.000 \\
(1.00) \\
\end{array}$ & $\begin{array}{r}-0.129 \\
(0.03) \\
\end{array}$ & $\begin{array}{r}-0.046 \\
(0.44)\end{array}$ & $\begin{array}{r}0.003 \\
(0.97) \\
\end{array}$ & $\begin{array}{r}0.007 \\
(0.91) \\
\end{array}$ & $\begin{array}{r}0.011 \\
(0.86) \\
\end{array}$ & $\begin{array}{r}0.019 \\
(0.75) \\
\end{array}$ & $\begin{array}{r}0.005 \\
(0.93) \\
\end{array}$ & $\begin{array}{r}0.002 \\
(0.98) \\
\end{array}$ & $\begin{array}{r}0.019 \\
(0.75) \\
\end{array}$ & $\begin{array}{r}0.098 \\
(0.11) \\
\end{array}$ & $\begin{array}{r}0.025 \\
(0.69) \\
\end{array}$ \\
\hline
\end{tabular}

are an unbiased proxy for expected returns. Our new approach yields several fresh insights regarding the determinants of the cross-section of returns.

First and foremost, we document that the market beta plays a much more important role in the cross-section of expected returns than previously reported. The market beta is significantly priced in most of our cross-sectional regressions even after we control for popular characteristics such as size, book-to-market, and prior returns.

Our beta-pricing result contrasts with Fama and French (1992), who show that the market beta does not have any explanatory power with and without the size and book-to-market factors. Instead, our finding lends support to Kothari et al. (1995). Kothari et al. estimate 
market betas from regressing annual portfolio returns onto the annual equally weighted market returns, finding economically and statistically significant compensation (about 6-9\% per annum) for beta risk. Our result is also consistent with Brav et al. (2003). Those authors use analyst forecasts to construct expected returns and also find a positive and robust relation between expected returns and market beta.

Second, we find that the ex-ante market, SMB, and HML returns are significantly positive and generally countercyclical. This evidence lends support to Fama and French (1993, 1995, 1996), who argue that size and book-to-market factors are ex-ante priced risk factors. In this regard, our result differs from Brav et al. (2003), who find that high book-to-market firms are not expected to earn higher returns than low book-to-market firms (a finding that is inconsistent with the notion that book-to-market is a risk factor).

Our evidence on the countercyclicality of the expected value premium lends support to studies emphasizing the effect of conditional information on the value premium. Ferson and Harvey (1999) show that loadings on aggregate predictive variables provide significant crosssectional explanatory power for stock returns even after controlling for the Fama-French factors. Lettau and Ludvigson (2001) show that value stocks are more correlated with consumption growth than growth stocks in bad times when risk or risk premium is high. ${ }^{9}$ A theoretical explanation of the countercyclical expected value premium is provided by Zhang (2005). He argues that it is more costly for firms to reduce than to expand capital. In bad times, firms want to scale down, especially value firms that are less productive than growth firms. Because scaling down is difficult, value firms are more adversely affected by economic downturns.

Finally, we find that there are no ex-ante positive momentum profits. More exactly, momentum is priced ex-ante, but with a negative sign. Brav et al. (2003) report a similar finding using alternative ex-ante return measures. This evidence is consistent with several interpretations. For example, investors may expect stocks with high prior returns to be less risky and to have lower returns in the future than stocks with low prior returns. Then

\footnotetext{
${ }^{9}$ Subsequent studies that use different econometric techniques but reach similar conclusion include Ang and Chen (2004), Jostova and Philipov (2004), Petkova and Zhang (2004), and Anderson et al. (2005). But Lewellen and Nagel (2004) highlight that the covariance between the value beta and the expected market risk premium is too small to explain the value anomaly within the conditional CAPM.
} 
positive momentum profits in ex-post returns come as a surprise to investors, and hence do not show up in ex-ante returns. This interpretation suggests that momentum profits result from systematic mispricing due to, e.g., conservatism (Barberis et al. (1998)), self-attributive overconfidence (Daniel et al. (1998)), and slow information diffusion (Hong and Stein (1999)).

Alternatively, the ex-ante distribution of stock returns perceived by investors may deviate from the ex-post distribution of stock returns (e.g., Brav and Heaton (2002) and Lewellen and Shanken (2002)). According to this argument, investors must learn about economic fundamentals because of incomplete information. As a result, the ex-ante return distribution perceived by investors often deviates from the ex-post return distribution. Shanken (2004) highlights that this deviation can affect the interpretation of asset pricing tests. In particular, ex-post returns can appear predictable to econometricians, but investors might neither perceive nor exploit this predictability ex-ante. This interpretation does not rely on mispricing.

Finally, momentum profits are likely an empirical by-product of using average realized returns as expected returns. In other words, momentum might arise from the use of average realized returns as a poor proxy for expected returns. Our evidence, coupled with the fact that implementing momentum strategies requires frequent trading in securities with disproportionately high transaction costs (e.g., Lesmond et al. (2004)), suggests that momentum may be an illusion of profit opportunity when, in fact, none exists.

While we do not claim that our ex-ante return measures should dominate any other measures, we believe that reexamining basic inferences in empirical finance with alternative proxies for investor expectations is a valid, relevant experiment. Because our proposed measure captures information that - both on theoretical and empirical grounds - is imperfectly correlated with ex-post average returns, we believe that experiments like ours can provide for fresh insights in to the economic determinants of the cross-section of expected returns. 
Table 11 : The Cross-Section of Expected Equity Risk Premium: Robustness Checks

This table reports the Fama-MacBeth cross-sectional regressions of expected excess returns on the factor loadings as well as firm characteristics such as size, book-to-market, and past returns. We estimate factor loadings using 60-month (or at least 24-month) rolling regressions of equity excess returns onto the Fama-French three factors and the WML excess returns. In the rolling regressions, we use both realized returns (with betas denoted $\beta_{\mathrm{MKT}}, \beta_{\mathrm{SMB}}, \beta_{\mathrm{HML}}$, and $\beta_{\mathrm{WML}}$ ) and constructed expected returns (with betas denoted $\widetilde{\beta}_{\mathrm{MKT}}, \widetilde{\beta}_{\mathrm{SMB}}, \widetilde{\beta}_{\mathrm{HML}}$, and $\widetilde{\beta}_{\mathrm{WML}}$ ). The $t$-statistics reported in parentheses are adjusted for autocorrelations of up to 12 lags, and are estimated with GMM. All the regression coefficients are in annualized percent. Expected returns are constructed using two alternative specifications of $\frac{\partial S_{i t}}{\partial B_{i t}}$.

\begin{tabular}{|c|c|c|c|c|c|c|c|c|c|c|c|c|c|}
\hline \multicolumn{7}{|c|}{ Panel A: $\frac{\partial S_{i t}}{\partial B_{i t}}=\alpha_{0}+\alpha_{1} \frac{B_{i t}}{S_{i t}}+\alpha_{2} \sigma_{i t}+\alpha_{3} r_{t}+\varepsilon_{i t}$} & \multicolumn{7}{|c|}{$\begin{array}{l}\text { Panel B: } \frac{\partial S_{i t}}{\partial B_{i t}}=\alpha_{0}+\alpha_{1} \frac{B_{i t}}{S_{i t}}+\alpha_{2} \sigma_{i t}+\alpha_{3} r_{t} \\
\quad+\alpha_{4} \log \left(\mathrm{ME}_{i t}\right)+\alpha_{5} \frac{\mathrm{BE}_{i t}}{\mathrm{ME}_{i t}}+\alpha_{6} r_{i t}^{12}+\varepsilon_{i t}\end{array}$} \\
\hline \multicolumn{4}{|c|}{ Covariance-Based Tests } & \multicolumn{3}{|c|}{ Characteristic-Based Tests } & \multicolumn{4}{|c|}{ Covariance-Based Tests } & \multicolumn{3}{|c|}{ Characteristic-Based Tests } \\
\hline & Model 1 & Model 2 & Model 3 & & Model 7 & Model 8 & & Model 1 & Model 2 & Model 3 & & Model 7 & Model 8 \\
\hline Intercept & $\begin{array}{r}2.923 \\
(5.35)\end{array}$ & $\begin{array}{r}2.703 \\
(4.95)\end{array}$ & $\begin{array}{r}2.934 \\
(4.80)\end{array}$ & Intercept & $\begin{array}{r}14.019 \\
(6.49)\end{array}$ & $\begin{array}{r}12.552 \\
(5.71)\end{array}$ & Intercept & $\begin{array}{r}3.259 \\
(6.31)\end{array}$ & $\begin{array}{r}3.597 \\
(6.60)\end{array}$ & $\begin{array}{r}3.784 \\
(6.11)\end{array}$ & Intercept & $\begin{array}{r}9.959 \\
(5.33)\end{array}$ & $\begin{array}{r}8.329 \\
(4.55)\end{array}$ \\
\hline$\beta_{\mathrm{MKT}}$ & $\begin{array}{r}3.088 \\
(5.18)\end{array}$ & $\begin{array}{r}2.048 \\
(4.84)\end{array}$ & $\begin{array}{l}1.624 \\
(3.78)\end{array}$ & $\beta_{\mathrm{MKT}}$ & $\begin{array}{r}2.018 \\
(4.58)\end{array}$ & $\begin{array}{r}2.082 \\
(4.46)\end{array}$ & $\beta_{\mathrm{MKT}}$ & $\begin{array}{r}2.876 \\
(4.30)\end{array}$ & $\begin{array}{r}1.633 \\
(3.47)\end{array}$ & $\begin{array}{l}1.013 \\
(2.21)\end{array}$ & $\beta_{\mathrm{MKT}}$ & $\begin{array}{r}1.835 \\
(3.76)\end{array}$ & $\begin{array}{r}1.920 \\
(3.88)\end{array}$ \\
\hline$\beta_{\mathrm{SMB}}$ & & $\begin{array}{r}3.038 \\
(11.76)\end{array}$ & $\begin{array}{r}3.207 \\
(11.68)\end{array}$ & $\log (\mathrm{ME})$ & $\begin{array}{l}-1.698 \\
(-7.80)\end{array}$ & $\begin{array}{l}-1.460 \\
(-6.85)\end{array}$ & $\beta_{\mathrm{SMB}}$ & & $\begin{array}{c}2.335 \\
(9.10)\end{array}$ & $\begin{array}{r}2.486 \\
(8.96)\end{array}$ & $\log (\mathrm{ME})$ & $\begin{array}{l}-1.223 \\
(-6.34)\end{array}$ & $\begin{array}{l}-0.960 \\
(-5.05)\end{array}$ \\
\hline$\beta_{\mathrm{HML}}$ & & $\begin{array}{r}1.590 \\
(3.90)\end{array}$ & $\begin{array}{r}1.659 \\
(3.56)\end{array}$ & $\mathrm{BE} / \mathrm{ME}$ & $\begin{array}{r}4.496 \\
(4.43)\end{array}$ & $\begin{array}{r}4.605 \\
(4.29)\end{array}$ & $\beta_{\mathrm{HML}}$ & & $\begin{array}{l}1.574 \\
(4.21)\end{array}$ & $\begin{array}{l}1.492 \\
(3.52)\end{array}$ & $\mathrm{BE} / \mathrm{ME}$ & $\begin{array}{r}5.728 \\
(5.34)\end{array}$ & $\begin{array}{r}5.961 \\
(5.84)\end{array}$ \\
\hline$\beta_{\mathrm{WML}}$ & & & $\begin{array}{r}15.210 \\
(0.54)\end{array}$ & Past Returns & & $\begin{array}{l}-0.130 \\
(-0.21)\end{array}$ & $\beta_{\mathrm{WML}}$ & & & $\begin{array}{r}-43.673 \\
(-0.64)\end{array}$ & Past Returns & & $\begin{array}{r}0.790 \\
(0.71)\end{array}$ \\
\hline Average $R^{2}$ & 0.031 & 0.186 & 0.218 & Average $R^{2}$ & 0.398 & 0.415 & Average $R^{2}$ & 0.022 & 0.112 & 0.135 & Average $R^{2}$ & 0.192 & 0.222 \\
\hline Intercept & $\begin{array}{r}7.888 \\
(20.82)\end{array}$ & $\begin{array}{r}5.948 \\
(20.94)\end{array}$ & $\begin{array}{r}5.335 \\
(21.92)\end{array}$ & Intercept & $\begin{array}{r}20.491 \\
(6.93)\end{array}$ & $\begin{array}{r}20.256 \\
(6.56)\end{array}$ & Intercept & $\begin{array}{r}7.055 \\
(18.36)\end{array}$ & $\begin{array}{r}5.061 \\
(22.45)\end{array}$ & $\begin{array}{r}4.679 \\
(20.63)\end{array}$ & Intercept & $\begin{array}{c}3.703 \\
(2.02)\end{array}$ & $\begin{array}{r}1.975 \\
(0.79)\end{array}$ \\
\hline$\widetilde{\beta}_{\mathrm{MKT}}$ & $\begin{array}{l}1.022 \\
(2.76)\end{array}$ & $\begin{array}{r}2.133 \\
(4.41)\end{array}$ & $\begin{array}{r}2.311 \\
(4.49)\end{array}$ & $\widetilde{\beta}_{\mathrm{MKT}}$ & $\begin{array}{r}0.676 \\
(2.48)\end{array}$ & $\begin{array}{r}0.688 \\
(2.64)\end{array}$ & $\widetilde{\beta}_{\mathrm{MKT}}$ & $\begin{array}{c}1.082 \\
(3.22)\end{array}$ & $\begin{array}{r}2.290 \\
(4.77)\end{array}$ & $\begin{array}{r}2.442 \\
(4.83)\end{array}$ & $\widetilde{\beta}_{\mathrm{MKT}}$ & $\begin{array}{r}0.903 \\
(2.83)\end{array}$ & $\begin{array}{r}0.939 \\
(2.96)\end{array}$ \\
\hline$\widetilde{\beta}_{\mathrm{SMB}}$ & & $\begin{array}{l}1.316 \\
(3.18)\end{array}$ & $\begin{array}{c}1.482 \\
(3.27)\end{array}$ & $\log (\mathrm{ME})$ & $\begin{array}{l}-2.305 \\
(-5.64)\end{array}$ & $\begin{array}{l}-2.187 \\
(-5.31)\end{array}$ & $\widetilde{\beta}_{\mathrm{SMB}}$ & & $\begin{array}{c}0.424 \\
(1.12)\end{array}$ & $\begin{array}{r}0.468 \\
(1.14)\end{array}$ & $\log (\mathrm{ME})$ & $\begin{array}{l}-0.240 \\
(-1.04)\end{array}$ & $\begin{array}{l}-0.084 \\
(-0.21)\end{array}$ \\
\hline$\widetilde{\beta}_{\mathrm{HML}}$ & & $\begin{array}{c}3.664 \\
(3.25)\end{array}$ & $\begin{array}{r}4.280 \\
(3.68)\end{array}$ & $\mathrm{BE} / \mathrm{ME}$ & $\begin{array}{r}7.436 \\
(10.56)\end{array}$ & $\begin{array}{r}7.057 \\
(10.19)\end{array}$ & $\widetilde{\beta}_{\mathrm{HML}}$ & & $\begin{array}{c}5.249 \\
(5.57)\end{array}$ & $\begin{array}{r}5.616 \\
(5.69)\end{array}$ & $\mathrm{BE} / \mathrm{ME}$ & $\begin{array}{r}7.080 \\
(8.44)\end{array}$ & $\begin{array}{r}7.149 \\
(8.59)\end{array}$ \\
\hline$\widetilde{\beta}_{\mathrm{WML}}$ & & & $\begin{array}{l}-5.007 \\
(-5.47)\end{array}$ & Past Returns & & $\begin{array}{l}-3.413 \\
(-3.97)\end{array}$ & $\widetilde{\beta}_{\mathrm{WML}}$ & & & $\begin{array}{l}-2.321 \\
(-2.31)\end{array}$ & $\begin{array}{l}\text { Past Returns } \\
(0.74)\end{array}$ & & 0.726 \\
\hline Average $R^{2}$ & 0.075 & 0.240 & 0.295 & Average $R^{2}$ & 0.351 & 0.365 & Average $R^{2}$ & 0.074 & 0.239 & 0.274 & Average $R^{2}$ & 0.185 & 0.204 \\
\hline
\end{tabular}




\section{References}

Altman, E. I. and V. M. Kishore, 1998, Default and returns on high yield bonds: analysis through 1997, working paper, NYU Solomon Center.

Anderson, T. G., T. Bollerslev, F. X. Diebold, and J. G. Wu, 2005, A framework for exploring the macroeconomic determinants of systematic risk, forthcoming, American Economic Review Papers and Proceedings.

Ang, A. and J. Chen, 2004, CAPM over the long-run: 1926-2001, working paper, Columbia University.

Banz, R. W., 1981, The relationship between return and market value of common stocks, Journal of Financial Economics, 9: 3-18.

Barberis, N., A. Shleifer, and R. Vishny, 1998, A model of investor sentiment, Journal of Financial Economics, 49: 307-343.

Bekaert, G., E. Engstrom, and S. Grenadier, 2004, Stock and bond returns with moody investors, working paper, Columbia Business School.

Black, F. and M. Scholes, 1973, The pricing of options and corporate liabilities, Journal of Political Economy, 81: 637-654.

Blanchard, O. J., 1993, Movements in the equity premium, Brookings Papers on Economic Activity, 2: 75-138.

Blume, M. E. and I. Friend, 1973, A new look at the capital asset pricing model, Journal of Finance, 28: 19-33.

Brav. A. and J. B. Heaton, 2002, Competing theories of financial anomalies, Review of Financial Studies, 15: 475-506.

Brav, A., R. Lehavy, and R. Michaely, 2003, Using expectations to test asset pricing models, working paper, Duking University.

Campbell, J., 1987, Stock returns and term structure, Journal of Financial Economics, 18: 373-399.

Campbell J. and G. Taksler, 2003, Equity volatility and corporate bond yields, Journal of Finance, forthcoming.

Chan, L. K. C., J. Karceski, and J. Lakonishok, 2003, The Level and Persistence of Growth Rates, Journal of Finance, 57: 643-684.

Chen, L., D. Lesmond, and J. Wei, 2003, Corporate yield spreads and bond liquidity, working paper.

Chen, N., R. Roll, and S. Ross, 1986, Economic forces and the stock Market, Journal of Business, 59: 383-403. 
Cochrane, J. H., 2001, Asset pricing, Princeton University Press, Princeton, New Jersey.

Collin-Dufresne, P. and R. S. Goldstein, 2001, Do credit spread reflects stationary leverage ratios?, Journal of Finance, 56: 1929-1957.

Collin-Dufresne, P., R. S. Goldstein, and S. Martin, 2001, The determinants of credit spreads, Journal of Finance, 56: 2177-2208.

Daniel, K., D. Hirshleifer, and A. Subrahmanyam, 1998, Investor psychology and capital asset pricing, Journal of Finance, 53: 1839-1885.

Duffee, G., 1999, Estimating the price of default risk, Review of Financial Studies, 12: 197-226.

Elton, E. J., 1999, Expected return, realized return, and asset pricing tests, Journal of Finance, 54: 1199-1220.

Elton, E. J., M. J. Gruber, D. Agrawal, and C. Mann, 2001, Explaining the rate spread of corporate bonds?, Journal of Finance, 56: 247-278.

Fama, E. F. and K. R. French, 1989, Business conditions and the expected returns on bonds and stocks, Journal of Financial Economics, 25: 23-50.

Fama, E. F. and K. R. French, 1992, The cross-section of expected stock returns, Journal of Finance, 47: 427-465.

Fama, E. F. and K. R. French, 1993, Common risk factors in the returns on stocks and bonds, Journal of Financial Economics, 33: 3-56.

Fama, E. F. and K. R. French, 1995, Size and book-to-market factors in earnings and returns, Journal of Finance, 50: 131-155.

Fama, E. F. and K. R. French, 1996, multi-factor Explanations of Asset Pricing Anomalies, Journal of Finance, 51: 55-84.

Fama, E. F., and K. R. French, 2002, The equity premium, Journal of Finance, 57: 637-659.

Fama, E. F., and J. MacBeth, 1973, Risk, return, and equilibrium: Empirical tests, Journal of Political Economy, 81: 607-636.

Ferson, W. and C. R. Harvey, 1991, The Variation of Economic Risk Premiums, Journal of Political Economy, 99: 385-415.

Ferson W. and C. R. Harvey, 1999, Conditioning variables and the cross-section of stock returns, Journal of Finance, 54: 1325-1360.

Gebhardt, W. R., C. M. C. Lee, and B. Swaminathan, 2001, Towards an implied cost of capital, Journal of Accounting Research, 39: 135-176. 
Gomes, J. F., L. Kogan, and L. Zhang, 2003, Equilibrium cross section of returns, Journal of Political Economy, 111: 693-732.

Graham, J., and C. R. Harvey, 2003, Expectations of equity risk premia, volatility and asymmetry from a corporate finance perspective, working paper, Duke University.

Harvey, C. R., 1986, Recovering expectations of consumption growth from an equilibrium model of the term structure of interest rates, thesis, University of Chicago.

Harvey, C. R., 1988, The real term structure and consumption growth, Journal of Financial Economics, 22: 305-333.

Harvey, C. R., 1991, The world price of covariance risk, Journal of Finance, 46: 111-157.

Hodrick, R. J. and E. C. Prescott, 1997, Postwar U.S. Business Cycles: An Empirical Investigation, Journal of Money, Credit, and Banking, 29: 1-16.

Hodrick, R. J. and X. Zhang, 2001, Evaluating the Specification Errors of Asset Pricing Models, Journal of Financial Economics, 62: 327-376.

Hong, H. and J. C. Stein, 1999, A unified theory of underreaction, momentum trading, and overreaction in asset markets, Journal of Finance, 54: 2143-2184.

Huang, M. and J. Huang, 2003, How much of the corporate-treasury yield spread is due to credit risk?, working paper, Stanford University.

Jegadeesh, N. and S. Titman, 1993, Returns to buying winners and selling losers: implications for stock market efficiency, Journal of Finance, 48: 65-91.

Jagannathan, R. and Z. Wang, 1996, The conditional CAPM and the cross-section of expected returns, Journal of Finance, 51: 3-53.

Jarrow, R., 1978, The relationship between yield, risk, and return of corporate bonds, Journal of Finance, 33: 1235-1240.

Jostova, G. and A. Philipov, 2004, Bayesian analysis of stochastic betas, forthcoming, Journal of Financial and Quantitative Analysis.

Keim, D. and R. Stambaugh, 1986, Predicting returns in the stock and bond markets, Journal of Financial Economics, 17: 357-390.

Kothari, S.P., J. Shanken, and R. G. Sloan, 1995, Another look at the cross-section of expected stock returns, Journal of Finance, 50: 185-224.

Lesmond, D. A., M. J. Schill, and C. Zhou, 2004, The illusory nature of momentum profits, Journal of Financial Economics, 71: 349-380.

Lettau, M. and S. Ludvigson, 2001, Resurrecting the (C)CAPM: A cross-sectional test when risk premia are time-varying, Journal of Political Economy, 109: 1238-1287. 
Lewellen, J. and J. Shanken, 2002, Learning, asset pricing tests, and market efficiency, Journal of Finance, 57: 1113-1146.

Lewellen, J. and N. Stefan, 2004, The conditional CAPM does not explain asset pricing anomalies, working paper, MIT.

Lintner, J. 1965, The valuation of risk assets and the selection of risky investments in stock portfolios and capital budgets, Review of Economics and Statistics, 47: 13-37.

Longstaff, L. and E. Schwartz, 1995, Valuing risky debt: A new approach, Journal of Finance, 50: 789-820.

Merton, R. C., 1973, An intertemporal capital asset pricing model, Econometrica, 41: 867887.

Merton, R. C., 1974, On the pricing of corporate debt: The risk structure of interest rates, Journal of Finance, 29: 449-470.

Miller, M. and M. Scholes, 1982, Dividends and Taxes: Some Empirical Evidence, Journal of Political Economy, 90: 1118-1141.

Petkova, R. and L. Zhang, 2004, Is value riskier than growth? forthcoming, Journal of Financial Economics.

Schwert, G. W., 2003, Anomalies and market efficiency, in George Constantinides, Milton Harris, and Rene Stulz, eds.: Handbook of the Economics of Finance (North-Holland, Amsterdam).

Shanken, J., 2004, Some thoughts on ex ante versus ex post asset pricing tests, working paper, Emory University.

Sharpe, W. F., 1964, Capital asset prices: A theory of market equilibrium under conditions of risk, Journal of Finance, 19: 425-442.

Sharpe, W. F., 1978, New evidence on the capital asset pricing model: Discussion, Journal of Finance, 33: 917-920.

Vassalou, M. and Y. Xing, 2004, Default risk in equity returns, Journal of Finance, 59: 831-868.

Zhang, L., 2005, The value premium, Journal of Finance, 60: 67-104 


\section{A Proofs}

Proof of Proposition 1: Let the uncertainty be represented by a $N$-dimensional Brownian motion $W_{t}=\left(w_{1 t}, w_{2 t}, \ldots, w_{N t}\right)^{\prime}$. There are $M$ firms, $F_{1}, F_{2}, \ldots, F_{M}$ whose asset values obey the following well-defined stochastic processes:

$$
\frac{d F_{i t}}{F_{i t}}=\mu_{i t} d t+\sigma_{i t}^{\prime} d W_{t}
$$

where $i=1, \ldots, M$ and $\sigma_{i t} \equiv\left(\sigma_{1 t}^{i}, \sigma_{2 t}^{i}, \ldots, \sigma_{N t}^{i}\right)^{\prime}$. Following Merton (1974), we assume that all firms are levered with predetermined debt. For firm $i$, both the equity price $S_{i t}$ and debt value $B_{i t}$ will depend on the underlying asset value $F_{i t}$.

Assume that the state price density process, $\Lambda_{t}$, is given by:

$$
d \Lambda_{t}=\mu_{\Lambda t} d t+\sigma_{\Lambda t}^{\prime} d W_{t}
$$

It follows that firm $i$ 's expected excess return on its asset is given by:

$$
R_{F t}^{i}-r_{t}=-\operatorname{Cov}_{t}\left(\frac{d F_{i t}}{F_{i t}}, \frac{d \Lambda_{t}}{\Lambda_{t}}\right)
$$

where $R_{F t}^{i} \equiv \mathrm{E}_{t}\left[\frac{d F_{i t}}{F_{i t}}\right] / d t$ is the expected return on the assets, $\operatorname{Cov}_{t}\left(\frac{d F_{i t}}{F_{i t}}, \frac{d \Lambda_{t}}{\Lambda_{t}}\right)$ denotes the instantaneous conditional covariance (normalized by $d t$ ), and $r_{t} \equiv-\mu_{\Lambda t} / \Lambda_{t}$ is the real interest rate.

As equity $S_{i t}$ and debt $B_{i t}$ are contingent claims written on the same underlying productive asset, an application of Itô's lemma yields the risk premia for these two securities:

$$
\begin{aligned}
& R_{S t}^{i}-r_{t}=-\left(\frac{\partial S_{i t}}{\partial F_{i t}}\right)\left(\frac{F_{i t}}{S_{i t}}\right) \operatorname{Cov}_{t}\left(\frac{d F_{i t}}{F_{i t}}, \frac{d \Lambda_{t}}{\Lambda_{t}}\right) \\
& R_{B t}^{i}-r_{t}=-\left(\frac{\partial B_{i t}}{\partial F_{i t}}\right)\left(\frac{F_{i t}}{B_{i t}}\right) \operatorname{Cov}_{t}\left(\frac{d F_{i t}}{F_{i t}}, \frac{d \Lambda_{t}}{\Lambda_{t}}\right)
\end{aligned}
$$

Both equity risk and debt risk premia are determined by the systematic component of the underlying asset, $\operatorname{Cov}_{t}\left(\frac{d F_{i t}}{F_{i t}}, \frac{d \Lambda_{t}}{\Lambda_{t}}\right)$. Equation (1) in Proposition 1 follows by taking the ratio of (A4) and (A5).

Proof of Proposition 2: Similar to Jarrow (1978), we start with the bond yield equation:

$$
B_{i t}=\sum_{j=1}^{n} C_{i} e^{-Y_{i t} T_{j}}+K_{i} e^{-Y_{i t} T_{n}}
$$

where $C_{i}$ is the coupon payment of the bond, $n$ is the number of remaining coupons, $Y_{i t}$ is the bond's yield to maturity, $T_{j}, j=1, \ldots, n$ are length of time period for each coupon 
payment, and $K_{i}$ is the face value of debt.

As the bond yield, $Y_{i t}$, is the only time-varying variable on the right-hand side of (A6), by Itô's Lemma we can write bond risk premium as a function of the bond yield and other observable bond characteristics:

$$
\frac{\mathrm{E}_{t}\left[d B_{i t}\right]}{B_{i t}}=\mathrm{E}_{t}\left[\frac{\partial B_{i t}}{\partial t} \frac{d t}{B_{i t}}+\frac{\partial B_{i t}}{\partial Y_{i t}} \frac{d Y_{i t}}{B_{i t}}+\frac{1}{2} \frac{\partial^{2} B_{i t}}{\partial Y_{i t}^{2}} \frac{1}{B_{i t}}\left(d Y_{i t}\right)^{2}\right]
$$

where

$$
\begin{aligned}
\frac{\partial B_{i t}}{\partial t} & =Y_{i t} B_{i t} \\
\frac{\partial B_{i t}}{\partial Y_{i t}} & =-H_{i t} B_{i t} \quad \text { with } \quad H_{i t}=\sum_{j=1}^{n} \frac{T_{j} C_{i} e^{-Y_{i t} T_{j}}}{B_{i t}}+\frac{T_{n} K_{i} e^{-Y_{i t} T_{n}}}{B_{i t}} \\
\frac{\partial^{2} B_{i t}}{\partial Y_{i t}^{2}} & =G_{i t} D_{i t} \quad \text { with } \quad G_{i t} \equiv \sum_{j=1}^{n} \frac{T_{j}^{2} C_{i} e^{-Y_{i t} T_{j}}}{B_{i t}}+\frac{T_{n}^{2} K_{i} e^{-Y_{i t} T_{n}}}{B_{i t}}
\end{aligned}
$$

and $H_{i t}$ and $G_{i t}$ are modified duration and convexity, respectively. (A7) thus becomes:

$$
R_{B t}^{i}-r_{t}=\mathrm{E}_{t}\left[\frac{d B_{i t}}{B_{i t}}\right] / d t-r_{t}=\left(Y_{i t}-r_{t}\right)-H_{i t} \frac{\mathrm{E}_{t}\left[d Y_{i t}\right]}{d t}+\frac{1}{2} G_{i t} \frac{\left(d Y_{i t}\right)^{2}}{d t}
$$

Proof of Proposition 3: The proposition follows by combining (2) with:

$$
\begin{aligned}
\mathrm{E}_{t}\left[d Y_{i t}\right] & =\pi_{i t} \mathrm{E}_{t}\left[d Y_{i t}^{-}\right]+\left(1-\pi_{i t}\right) \mathrm{E}_{t}\left[d Y_{i t}^{+}\right] \\
\left(d Y_{i t}\right)^{2} & =\pi_{i t}\left(d Y_{i t}^{-}\right)^{2}+\left(1-\pi_{i t}\right)\left(d Y_{i t}^{+}\right)^{2}
\end{aligned}
$$

